


\section{Waarden van het label Nationaal Park voor Nationaal Park Weerribben-Wieden}

C.M. Goossen

Dit onderzoek is uitgevoerd door Wageningen Environmental Research (Alterra) in opdracht van en gefinancierd door het Nationaal Park Weerribben-Wieden (projectnummer 5200043248).

Wageningen Environmental Research

Wageningen, maart 2017

Rapport 2798

ISSN 1566-7197 
Goossen, C.M., 2017. Waarden van het label Nationaal Park voor Nationaal Park Weerribben-Wieden. Wageningen, Wageningen Environmental Research, Rapport 2798. 46 blz.; 4 fig.; 10 tab.; 41 ref.

Dit rapport beschrijft de effecten van het dragen van het label Nationaal Park op het bezoek aan natuurgebied Weerribben-Wieden. Uit een panelonderzoek blijkt dat $25 \%$ zegt dat het label Nationaal Park een (doorslaggevende) rol heeft gespeeld bij de beslissing om het natuurgebied te bezoeken. Van de Nederlanders zegt 34\% gevoelig voor het label 'Nationaal Park' te zijn. Een directe invloed op het bezoek aan de Weerribben-Wieden is beperkt. Uit dit onderzoek blijkt dat vooral toeristen de economische waarden van het label Nationaal Park voor de Weerribben-Wieden bepalen en de bewoners vooral de sociaal-emotionele waarden van het label. De economische toegevoegde waarde van het label kan geschat worden tussen de $10 \%$ en $40 \%$. De sociaal-emotionele waarden zijn belangrijk voor het vergroten van het ecologisch en economisch belang van een Nationaal Park. Het draagvlak voor het behoud en bescherming van natuurgebieden kan ermee worden vergroot. De affiniteit van mensen die daarvoor nodig is, is in en rond de Weerribben-Wieden aanwezig.

Trefwoorden: Nationaal Park, bestedingen, gebruikswaarde, niet-gebruikswaarde, onderzoek.

Dit rapport is gratis te downloaden van http://dx.doi.org/10.18174/411141 of op www.wur.nl/environmental-research (ga naar 'Wageningen Environmental Research' in de grijze balk onderaan). Wageningen Environmental Research verstrekt geen gedrukte exemplaren van rapporten.

2016 Wageningen Environmental Research (instituut binnen de rechtspersoon Stichting Wageningen Research), Postbus 47, 6700 AA Wageningen, T 03174807 00, E info.alterra@wur.nl, www.wur.nl/environmental-research. Wageningen Environmental Research is onderdeel van Wageningen University \& Research.

- Overname, verveelvoudiging of openbaarmaking van deze uitgave is toegestaan mits met duidelijke bronvermelding.

- Overname, verveelvoudiging of openbaarmaking is niet toegestaan voor commerciële doeleinden en/of geldelijk gewin.

- Overname, verveelvoudiging of openbaarmaking is niet toegestaan voor die gedeelten van deze uitgave waarvan duidelijk is dat de auteursrechten liggen bij derden en/of zijn voorbehouden.

Wageningen Environmental Research aanvaardt geen aansprakelijkheid voor eventuele schade voortvloeiend uit het gebruik van de resultaten van dit onderzoek of de toepassing van de adviezen.

Wageningen Environmental Research Rapport 2798 | ISSN 1566-7197

Foto omslag: C.M. Goossen 


\section{Inhoud}

$\begin{array}{ll}\text { Samenvatting } & \mathbf{5}\end{array}$

$1 \quad$ Inleiding $\quad 11$

1.1 Probleemstelling 11

$\begin{array}{lll}1.2 \text { Werkwijze } & 12\end{array}$

$2 \quad$ Resultaten uit de literatuur $\quad 13$

$\begin{array}{lll}2.1 & \text { Inleiding } & 13\end{array}$

$\begin{array}{lll}2.2 & \text { Sociaal-emotionele waarde } & 13\end{array}$

$\begin{array}{lll}2.3 & \text { Economische waarde van een label } & 14\end{array}$

$\begin{array}{lll}2.4 & \text { Effecten van het label } & 15\end{array}$

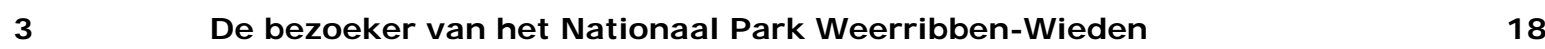

$\begin{array}{lll}3.1 & \text { Inleiding } & 18\end{array}$

$\begin{array}{lll}3.2 & \text { Type bezoeker } & 18\end{array}$

$\begin{array}{lll}3.3 & \text { Recreatieactiviteiten } & 20\end{array}$

$\begin{array}{lll}3.4 & \text { Bestedingen } & 22\end{array}$

3.5 Waardering $\quad 24$

$\begin{array}{lll}3.6 & \text { Redenen voor bezoek } & 24\end{array}$

4 De waarden van het label Nationaal Park $\quad 27$

$\begin{array}{lll}4.1 & \text { Inleiding } & 27\end{array}$

4.2 Betekenis label 'Nationaal Park' in het algemeen $\quad 27$

$\begin{array}{lll}4.3 & \text { Waarden van het label voor Weerribben-Wieden } & 28\end{array}$

$\begin{array}{lll}4.4 & \text { Sociaal-emotionele waarden } & 29\end{array}$

4.5 De economische effecten van het label Nationaal Park $\quad 31$

$5 \quad$ Conclusies en aanbevelingen $\quad 32$

5.1 Inleiding $\quad 32$

$\begin{array}{lll}5.2 & \text { Conclusies } & 32\end{array}$

5.3 Aanbevelingen 34

$\begin{array}{ll}\text { Literatuur } & \mathbf{3 7}\end{array}$

$\begin{array}{lll}\text { Bijlage } 1 & \text { Recreatieactiviteiten } & 39\end{array}$

$\begin{array}{lll}\text { Bijlage } 2 & \text { Bestedingen } & \mathbf{4 0}\end{array}$

Bijlage $3 \quad$ Redenen voor bezoek $\quad 41$ 



\section{Samenvatting}

Voor de gemeente Steenwijkerland is een sterk en herkenbaar Nationaal Park Weerribben-Wieden belangrijk vanwege de betekenis voor de vrijetijdseconomie. Door een natuurgebied een label te geven, geeft het aan over unieke kenmerken te beschikken zodat een consument het herkent en waarmee een natuurgebied zich onderscheidt van andere natuurgebieden en een eigen identiteit krijgt. Kenmerkend van het label 'Nationaal Park' is een algemeen hoge kwaliteit van de natuurlijke omgeving en een goed opgezette toeristische infrastructuur. Eigenaren, beheerders en andere betrokken partijen dragen samen de verantwoordelijkheid voor de bescherming en ontwikkeling van de kwaliteit van het Nationaal Park. Deze stakeholders in en rond het Nationaal Park WeerribbenWieden willen weten wat de toegevoegde waarde van het label Nationaal Park anno 2016 is. De vragen zijn dan ook:

- Wat is de invloed van het label Nationaal Park op de beslissing van toeristen om de WeerribbenWieden te bezoeken?

- Wat is de toegevoegde waarde van het label Nationaal Park?

Om de probleemstelling te kunnen beantwoorden is een beperkte (inter) nationaal literatuuronderzoek uitgevoerd en een online onderzoek uitgevoerd via een onderzoekpanel bestaande uit personen van 18 jaar en ouder. Alleen bezoekers die de afgelopen 12 maanden een bezoek hadden gebracht aan natuurgebied Weerribben-Wieden zijn ondervraagd. Dit heeft een respons opgeleverd van 1116 personen. De antwoorden zijn representatief gemaakt voor Nederland op basis van een weging op geslacht, leeftijd, opleiding en provincie op randtotalen.

Op basis van het literatuuronderzoek is er geen eenduidig beeld van het effect van het dragen van het label Nationaal Park op het bezoek, maar dat het label wel gepaard gaat met diverse waarden. In de literatuur wordt een onderscheid gemaakt tussen gebruikswaarde en niet-gebruikswaarde. De gebruikswaarde is de mate waarin het natuurgebied daadwerkelijk gebruikt wordt en hoe vaak. De economische waarde is sterk gekoppeld aan de gebruikswaarde. De niet-gebruikswaarde wordt omschreven als de welvaart die mensen ontlenen aan natuur zonder dat zij er gebruik van maken. Hierbij kan een onderscheid gemaakt worden tussen een bestaanswaarde, een verervingswaarde, een optiewaarde en een altruïstische waarde. De bestaanswaarde is gelijk aan de waarde die de huidige generatie hecht aan het bestaan van een ecosysteem, ongeacht gebruik. De verervingwaarde is de waarde die de mens hecht aan het open houden van de mogelijkheid van toekomstig gebruik door toekomstige generaties. Onder optiewaarde wordt de waarde verstaan die de mens hecht aan het open houden van de mogelijkheid van toekomstig gebruik door de huidige generatie. De altruïstische waarde is de waarde die mensen hechten aan het feit dat anderen een gebied kunnen bezoeken, zonder dat ze er zelf gebruik van maken. Deze sociaal-emotionele waarden hebben relaties met de affiniteit die mensen met een gebied hebben via de mate waarop mensen voelen dat ze deel uitmaken van een gebied, de mate van betrokkenheid met het gebied en de mate van verbondenheid met het gebied. Deze affiniteit van mensen met beschermde natuurgebieden is cruciaal voor het voortbestaan en succes van deze gebieden.

Uit het online-onderzoek blijkt dat het merendeel (52\%) van de bezoekers als dagbezoeker kan worden bestempeld, gevolgd door toeristen (35\%) en ten slotte bewoners ${ }^{1}(13 \%)$. Een dagbezoeker is een bezoeker van verder weg, maar maakt in het gebied geen overnachting. De dagbezoeker komt vooral uit Overijssel en de noordelijke drie provincies. De provincies Zuid- en Noord-Holland en NoordBrabant zijn de grootste leveranciers van toeristen voor Nationaal Park de Weerribben-Wieden. Circa

${ }^{1}$ Vooral uit de gemeenten Steenwijkerland, Meppel, Noordoostpolder en Weststellingwerf en minder uit Zwartewaterland, Staphorst en Westerveld. 
een derde (34\%) van alle bezoekers woont binnen een straal van $50 \mathrm{~km}$ van het Nationaal Park Weerribben-Wieden. De toeristen verblijven het meest (22\%) in Giethoorn en verblijven het meest op een camping (28\%). Een ruime meerderheid ( $80 \%$ ) van alle bezoekers bezoekt Nationaal Park Weerribben-Wieden één of enkele keren per jaar. Bewoners en toeristen bezoeken het park relatief vaker dan de dagbezoekers. De gemiddelde leeftijd van de bezoeker is 49 jaar. Dagbezoekers zijn iets jonger dan de bewoners en toeristen. Bijna een derde (32\%) van de bezoekers blijft langer dan 4 uur in het park. Gemiddeld blijft men ongeveer 3 uur in het Nationaal Park. Bewoners blijven significant korter dan dagbezoekers en toeristen. De gemiddelde groepsgrootte is 4,3 personen. Bijna 42 procent van de bezoekers komt met een partner. Bewoners gaan in verhouding vaker alleen op pad dan dagbezoekers en toeristen.

Wandelen (56\%) en fietsen (37\%) zijn de meest populaire activiteiten, gevolgd door een bezoek aan een café/restaurant (27\%) of aan een info/bezoekerscentrum (26\%). Wandelen en fietsen wordt significant meer gedaan door bewoners. Bezoekers die het natuurgebied Weerribben-Wieden vaker per jaar bezoeken, ondernemen in het algemeen de meer sportieve activiteiten. Opvallend is dat in het Nationaal Park Weerribben-Wieden 39 procent van de bezoekers iets huurt om het gebied te bekijken.

lets meer dan drie kwart (77\%) van de bezoekers geeft geld uit tijdens hun bezoek aan het Nationaal Park de Weerribben-Wieden, waarbij bewoners in verhouding meer aangeven geen geld te hebben uitgegeven. Gemiddeld besteedt een persoon $€ 15$,- per dag in of rond het Nationaal Park WeerribbenWieden (zonder kosten voor overnachtingen en inclusief personen die niets besteden). Bewoners besteden gemiddeld $€ 10$,- per dag; dagbezoekers gemiddeld $€ 12$,- en toeristen besteden gemiddeld (exclusief overnachtingskosten) $€ 25$,- per dag. Toeristen geven gemiddeld dus twee keer zoveel meer uit dan bewoners en dagbezoekers. Het meest wordt besteed in restaurants en cafés. En ook in de horeca geven toeristen twee keer zoveel meer uit dan bewoners en dagbezoekers.

Het gemiddelde rapportcijfer voor de waardering van het Nationaal Park Weerribben-Wieden is een 8,2. De bewoners waarderen het gebied hoger dan toeristen en dagbezoekers. Een meerderheid van de bezoekers is het er (zeer) mee eens dat de Weerribben-Wieden een heel mooi gebied is (93\%), belangrijk is voor het beschermen van de natuur $(87 \%)$, en dat de Weerribben-Wieden geschikt is om een middagje te ontspannen ( $90 \%$ ). Deze gebiedskwaliteiten zijn dus essentieel en instandhouding hiervan is zeer belangrijk voor de sector recreatie en toerisme.

Een belangrijk resultaat is dat het voor $24 \%$ van de bezoekers een belangrijke tot doorslaggevende rol heeft gespeeld bij hun beslissing om het gebied te bezoeken dat het een Nationaal Park was. Hoe meer men het park bezoekt, hoe belangrijker deze rol is. Het lijkt er dus op dat het label 'Nationaal Park' herhalingsbezoek stimuleert. Dagbezoekers en toeristen die vaker het gebied bezoeken vinden het in verhouding ook significant belangrijker dat het gebied een Nationaal park is. Dit zijn dus de vaste gasten ofwel de hardcore van het Nationaal Park. Maar belangrijkere redenen bij de beslissing om het gebied te bezoeken zijn rust en ontspanning en om gezellig tijd door te brengen met gezin / vrienden / familie. Maar ook om iets te leren over de natuur is een belangrijke reden evenals om Giethoorn te zien en dan gelijk het Nationaal Park mee te nemen in het bezoek. De meerderheid van de Nederlanders vindt niet dat het label 'Nationaal Park' voor de Weerribben-Wieden afgeschaft mag worden maar dat er juist extra geïnvesteerd moet worden in natuur en toerisme.

De toegevoegde waarde van het label wordt gevormd door de gebruikswaarde (bezoek en economische waarden) en de sociaal-emotionele waarden (niet-gebruikswaarde en affiniteit). Het label Nationaal Park geeft een gebied een specifieke status en schept verwachtingen over de kwaliteit en uniciteit. Zonder label zal de Weerribben-Wieden een natuurgebied zijn zoals alle andere natuurgebieden en dus niet speciaal. Daardoor is er voor een deel van de toeristen geen of minder reden meer om het te bezoeken (met name voor de label-gevoelige toeristen).

Zonder het label Nationaal Park zouden de label-gevoelige Nederlanders (34\%) wellicht niet meer komen en kan het bedrijfsleven rond het natuurgebied Weerribben-Wieden een omzetdaling krijgen tussen 2 en 9\%. Geconcludeerd kan worden de economische toegevoegde waarde van het label voor het natuurgebied Weerribben-Wieden geschat kan worden tussen de $10 \%$ en $40 \%$ waarbij het eerder naar de $10 \%$, omdat er een verschil is tussen wat mensen zeggen wat ze doen en daadwerkelijk doen. 
Uit dit onderzoek blijkt dat de niet-gebruikswaarde als onderdeel van de sociaal-emotionele waarden hoog is voor het Nationaal Park Weerribben-Wieden. Het gaat vooral om de optiewaarde (86\%), de altruïstische waarde (83\%), de bestaanswaarde ( $81 \%)$ en iets minder de verervingswaarde $(77 \%)$. Dit geldt vooral voor de bewoners.

De affiniteit met de Weerribben-Wieden is redelijk hoog te noemen. Dit komt vooral door het gevoel van verbondenheid en trots (en dan vooral bij bezoekers die er vaker komen en bij de bewoners), en minder door de betrokkenheid met het gebied. De betrokkenheid is groter bij bezoekers die er vaker komen. Een meerderheid zegt dat de Weerribben-Wieden een typisch Nederlands Nationaal Park is. Bewoners zeggen dit relatief vaker dan toeristen.

Nederlanders zijn gehecht aan de Nederlandse Nationale Parken want $81 \%$ zegt dat het (zeer) jammer zou zijn als Nederland geen Nationale Parken meer zou kennen. Voor 22\% maakt het echt een verschil of een natuurgebied een Nationaal Park is. Een Nationaal Park is volgens de Nederlanders dan ook een door de overheid beschermd natuurgebied met ongerepte natuur dat iets unieks heeft met goede recreatief-toeristische voorzieningen.

Uit dit onderzoek blijkt dat vooral toeristen de economische waarden van het label Nationaal Park voor de Weerribben-Wieden bepalen en de bewoners vooral de sociaal-emotionele waarden van het label. De sociaal-emotionele waarden zijn belangrijk voor het vergroten van het ecologisch en economisch belang van een Nationaal Park. Het draagvlak voor het behoud en bescherming van natuurgebieden kan ermee worden vergroot. De affiniteit van mensen die daarvoor nodig is, is in en rond de Weerribben-Wieden aanwezig.

Gezien de conclusies wordt aanbevolen dat het waardevol is om het label Nationaal Park voor de Weerribben-Wieden te behouden. Een heldere merkpositionering van het label Nationaal Park Weerribben-Wieden onderscheidt het gebied zich van andere natuurgebieden waarbij de nadruk kan worden gelegd op de volgende merkwaarden in relatie tot de activiteiten die worden ondernomen: bijzonder, verrassend, divers (natuur en activiteiten) en toegankelijk (voor ieder wat wils). Daarbij zal een verschil in promotie en promotiemiddelen gerelateerd moeten zijn aan de verwachtingen van de type bezoeker (bewoner, dagbezoeker, toerist). Het recreatief-toeristisch bedrijfsleven zal zich vooral en nog meer moeten richten op de dagbezoeker en de toerist. Dit kan in de vorm van aantrekkelijke arrangementen, het organiseren van diverse evenementen/lezingen en excursies. Met name de aantrekkingskracht van Giethoorn kan gebruikt worden om toeristen te verleiden het Nationaal Park te bezoeken. Dit kan door afspraken te maken met touroperators, horeca-ondernemers in Giethoorn via bijvoorbeeld een 'horeca-hopping' in de Weerribben-Wieden. Wellicht is zelfs te overwegen om een derde bezoekerscentrum te ontwikkelen in Giethoorn.

Het succes van de toegevoegde waarde van het label is ook te vergroten wanneer de beheerders zo goed mogelijk inspelen op de affiniteit van de bezoekers met het Nationaal Park. Dit zijn dan met name bewoners en bezoekers die er vaker komen. Het verspreiden van de nieuwsbrief onder de 'vrienden van' dat reeds wordt gedaan, is een goede manier om de affiniteit te behouden en mogelijk te vergroten. De ontvangers van de nieuwsbrief zijn een soort ambassadeurs van het natuurgebied en via de nieuwsbrief zijn er mogelijkheden om acties en evenementen te organiseren om de band met deze bezoekers te versterken. Een mogelijkheid is om bijvoorbeeld kortingsacties te geven indien ze andere toeristen overhalen om ook een bezoek te brengen aan de Weerribben-Wieden of ook een abonnement te nemen op de nieuwsbrief. Deze ambassadeurs zijn bij uitstek geschikt om het mentale beeld van Weerribben-Wieden van andere toekomstige bezoekers verder in te kleuren.

De opvatting van Nederlanders dat het natuurgebied als Nationaal Park een beschermde status heeft kan gevolgen hebben bij een gebiedsuitbreiding van het gebied. Een eventuele uitbreiding van het Nationaal Park Weerribben-Wieden zou dan bij voorkeur moeten gebeuren met gebieden die al een wettelijke status van bescherming bieden die Nederlanders verwachten van een Nationaal Park. Indien de uitbreiding gepaard gaat met gebieden die niet de wettelijke status van bescherming bieden en er worden activiteiten ondernomen die ten koste van de natuur zouden kunnen gaan (zoals bebouwing), dan zal dit wellicht weerstand opwekken bij de bezoekers. Dit kan komen omdat ze denken dat het gebied beschermd is en dat die activiteit niet thuis hoort in een beschermd natuurgebied. In de 
communicatie is het dan raadzaam te benadrukken dat het label Nationaal Park zelf het natuurgebied geen beschermde status geeft.

Een Nationaal Park roept verwachtingen op bij het publiek dat het weliswaar een beschermd gebied is, maar ook een uniek gebied met goede recreatief-toeristische voorzieningen. Dit brengt bepaalde verplichtingen met zich mee in het beheer en onderhoud van het natuurgebied. Het label werkt als een marker waarmee het gebied zich duidelijk onderscheid van andere natuurgebieden. Een marker heeft invloed op de perceptie van de toerist op het gebied en roept bepaalde connotaties op. Dit kan tot gevolg hebben dat een toerist het specifieke gebied wil gaan bezoeken. Het label Nationaal Park is een sterk internationaal merk en de Weerribben-Wieden kan op deze bekendheid meeliften. Het is in ieders belang dat de huidige hoge waardering van de Weerribben-Wieden gehandhaafd blijft door goede onderlinge afspraken te maken met de diverse stakeholders over een verdeling van de kosten van het beheer, onderhoud en promotie van het natuurgebied en de recreatief-toeristische voorzieningen.

De stakeholders van het Nationaal Park de Weerribben-Wieden hebben als doel de toegevoegde waarde van het label Nationaal Park te vergroten. Om dit te bereiken wijzen wij op de aanbevelingen van de Stichting Wetenschappelijk Onderzoek Commerciële Communicatie. Zij hebben 10 algemene ijkpunten van een sterk label opgesteld. Deze ijkpunten geven alle partijen inzicht in wat nodig is om een sterk label te ontwikkelen en bieden een afwegingskader met betrekking tot de inzet van mensen en middelen in bestaande en nieuwe marketingconcepten. Deze 10 ijkpunten van een sterk label zijn:

1. Beschikt over een onderscheidend concept.

2. Heeft een goede relatie met zijn omgeving.

3. Heeft een doel en een visie.

4. Is verankerd in het doen en laten van medewerkers.

5. Communiceert consequent en uniek.

6. Heeft online volgers.

7. Werkt samen met klanten.

8. Vitaliseert en innoveert.

9. Heeft een sterke positie in distributiekanalen.

10. Heeft investeerders.

Gezien het feit dat 34\% van de Nederlanders label-gevoelig is, is het raadzaam om in alle promotieen communicatie uitingen over de Weerribben-Wieden het label 'Nationaal Park' zichtbaar te voeren. Het effect van deze actie kan dan over twee a drie jaar onderzocht worden door dezelfde vragenlijst nogmaals af te nemen en te vergelijken met de resultaten van deze vragenlijst. De kosten van een dergelijk onderzoek worden geschat op $€ 15.000$,-

Om de economische impact van het Nationaal Park te vergoten is het op basis van de resultaten van dit onderzoek raadzaam om zich meer te richten op toeristen. Deze besteden meer in de horeca en besteden in het ook algemeen meer, zelfs indien de overnachtingskosten worden afgetrokken. Er lijkt nog groei te zitten in de bestedingen in de horeca, want driekwart van de bezoekers geeft aan geen bezoek te hebben gebracht aan de horeca. Wellicht komt dit omdat er te weinig horeca is. Of dat de ligging van de huidige horeca niet helemaal overeenkomt met de spreiding van de bezoekers over het gebied. Het verdient ook aanbeveling om gerichte acties te gaan ondernemen om bezoekers over te halen een bezoek te brengen aan de horeca.

Bewoners geven minder uit maar het is wel interessant om de absolute omvang van de bewoners, dagbezoekers en toeristen te onderzoeken. Daarmee kan de totale omzet worden bepaald en worden achterhaald hoe de verdeling tussen de bewoners, dagbezoekers en toeristen precies is. Daarvoor kan een monitoringsonderzoek worden opgesteld dat (eventueel jaarlijks en per dag) de omvang en de spreiding van het bezoek in de Weerribben-Wieden in kaart brengt in combinatie met een steekproef onder bezoekers naar die verdeling. Daarmee kan er invulling worden gegeven aan de sleutelelementen ASBTW (Goossen, 2016) die van belang zijn voor een goed functioneren van een Nationaal Park. De A staat voor Aantal bezoeken per jaar; de S voor Spreiding van bezoekers over het gebied; de B voor Bestedingen; de T voor Tevredenheid en de W voor Wensen van de bezoeker. Gegevens over de B en T zijn in dit rapport al opgenomen. Het verzamelen van data over de A, S en 
W is dan nog nodig. Er zijn voornemens bij de beheerder van het Nationaal Park Weerribben-Wieden om in 2017 de A en de W te laten onderzoeken. De Spreiding van de bezoekers over het gebied staat dan nog open. Inzicht in de spreiding is vooral voor de beheerder en de horeca belangrijk. Met nieuwe sensortechnieken is deze spreiding te achterhalen tegen geringe kosten. Globaal moet gedacht worden aan een eenmalig investering van $€ 7.500$,- en een jaarlijkse data-analyse van $€ 2.000,-$. Voordeel van deze sensortechniek is dat ook gelijk de A wordt onderzocht.

Nader onderzoek is ook nodig om het totaal aan indirecte bestedingen uit te zoeken om op deze wijze de economische impact van Nationaal Park Weerribben-Wieden op de regio te kunnen bepalen.

Uit de literatuur blijkt dat het label Nationaal Park anders werkt voor binnenlandse en buitenlandse toeristen. Buitenlandse toeristen komen eerder door de status van Nationaal Park dan lokale toeristen die andere motieven hebben om een gebied te bezoeken. Voor een vervolgonderzoek is het dus van belang om deze verdeling tussen binnenlandse en buitenlandse toeristen te maken en te analyseren. Een mogelijkheid hiervoor is om dit onderzoek te herhalen voor de buitenlandse toerist. Dit kan bijvoorbeeld via een online-vragenlijst door gebruik te maken van de email-adressen die het bedrijfsleven heeft van haar buitenlandse klanten. 


\section{$1 \quad$ Inleiding}

Yellowstone National Park in de Verenigde Staten is het eerste en daarmee het oudste Nationaal Park in de wereld. Het is opgericht in 1872 'ten behoeve van het genot van mensen' (Keefer, 1971). Nederland kent in 201620 Nationale Parken waarvan de Weerribben-Wieden er één is. Het gebied Weerribben-Wieden is meer dan 10.000 ha groot en bestaat uit twee delen: Weerribben en Wieden. Het ligt grotendeels in de gemeente Steenwijkerland. In het najaar van 2014 heeft de gemeente Steenwijkerland besloten om een nieuw perspectief voor het Nationaal Park Weerribben-Wieden te ontwikkelen, nadat de provincie Overijssel het Nationaal Park Weerribben-Wieden had uitgedaagd om een vernieuwende en actieve rol te spelen. De gemeente Steenwijkerland is voornemens om vanuit een regisserende rol de toekomst van het Nationaal Park voort te zetten. De gemeente zal dit doen in samenwerking met haar gebiedspartners (NPWW, 2015).

Voor de gemeente Steenwijkerland is een sterk en herkenbaar Nationaal Park Weerribben-Wieden belangrijk vanwege de betekenis voor de vrijetijdseconomie. Deze sector is voor de gemeente Steenwijkerland van wezenlijk belang. Landelijk gezien is de vrijetijdseconomie verantwoordelijk voor $4 \%$ van het aantal banen. Voor de gemeente Steenwijkerland ligt dat met $13 \%$ op het driedubbele (NPWW, 2015). Geschat wordt dat er circa 1,5 miljoen bezoekers jaarlijks het gebied aandoen (NPWW, 2010). Giethoorn, dat aan het Nationaal Park grenst, is een toeristische hotspot met een geschat aantal van 590.000 bezoekers in 2015 waarvan 205.000 uit het buitenland (Marketing Oost, 2016). Het Nationaal Park Weerribben-Wieden met haar unieke natuur en Giethoorn spelen een belangrijke rol in de aantrekkingskracht als toeristische regio. Het unieke natuurgebied dat in het Nationaal Park ligt, is het grootste aaneengesloten laagveenmoeras in Noordwest-Europa.

Konecnik \& Go (2008) stellen dat door een natuurgebied een label te geven, het aangeeft over unieke kenmerken te beschikken zodat een consument het herkent en waarmee een natuurgebied zich onderscheidt van andere natuurgebieden en een eigen identiteit krijgt. Het label Nationaal Park mag worden gevoerd wanneer een gebied een aaneengesloten natuurgebied is van meer dan 1000 hectare dat bestaat uit natuurterreinen, water en bossen met een bijzondere landschappelijke waarde (Elands, Van Marwijk, Jochem, Pouwels \& De Boer, 2005). Tevens geeft het label aan dat er bijzondere planten en dieren aanwezig zijn en een mogelijkheid biedt voor recreatief gebruik in het natuurgebied. Eagles (2001) stelt dat een kenmerkend brand identity van het label 'Nationaal Park' een algemeen hoge kwaliteit van de natuurlijke omgeving behelst en een goed opgezette toeristische infrastructuur. Het label Nationaal Park lijkt positieve associaties op te roepen met unieke natuurgebieden die mensen graag willen bezoeken. Zodoende wordt het label geïdentificeerd als een toeristische marker ((Leiper 1990; Lew 1987; MacCannell 1976; Richards 2002). Een marker kan informatie over een gebied zijn, een naam, een concept of een image of slechts een idee.

Eigenaren, beheerders en andere betrokken partijen dragen samen de verantwoordelijkheid voor de bescherming en ontwikkeling van de kwaliteit van het Nationaal Park (SNP, 2016). Deze stakeholders in en rond het Nationaal Park Weerribben-Wieden willen weten wat de toegevoegde waarde van het label Nationaal Park anno 2016 is. Komende jaren worden gerichte acties ondernomen om de toegevoegde waarde van het label Nationaal Park Weerribben-Wieden te vergroten.

\section{$1.1 \quad$ Probleemstelling}

Stakeholders in en rond het Nationaal Park Weerribben-Wieden vragen zich af of het label 'Nationaal Park' voldoende waarde heeft om toeristen te verleiden een bezoek te brengen aan het Nationaal Park Weerribben-Wieden. Er wordt gesuggereerd dat toeristen komen omdat het gebied aantrekkelijk is en het label daar niet veel invloed op heeft. Het doel van dit rapport is om een bijdrage te leveren aan de discussie rond het voeren van het label Nationaal Park Weerribben-Wieden.

De vragen zijn dan ook: 
1. Wat is de invloed van het label Nationaal Park op de beslissing van toeristen om de WeerribbenWieden te bezoeken?

2. Wat is de toegevoegde waarde van het label Nationaal Park?

\subsection{Werkwijze}

Om de probleemstelling te kunnen beantwoorden is een beperkte (inter) nationaal literatuuronderzoek uitgevoerd naar de werking en betekenis van het label Nationaal Park. Op basis van de uitkomsten van het literatuuronderzoek is een online onderzoek uitgevoerd. Bureau GfK heeft dit onderzoek in opdracht van Wageningen Environmental Research (voorheen Alterra) uitgevoerd met behulp van hun onderzoekpanel bestaande uit personen van 18 jaar en ouder. Om een hoge respons te krijgen is gebruik gemaakt van het screeningsonderzoek van GfK van eind november 2016, waarbij allerlei specifieke vragen zijn gesteld aan het hele panel van 55 tot 60.000 personen. Eén van de vragen was of ze afgelopen 12 maanden een bezoek hadden gebracht aan natuurgebied Weerribben-Wieden. Dit betekent dat alleen bezoekers zijn ondervraagd en niet de niet-bezoekers. Ook de niet-bezoekers kunnen echter een bepaalde waarde hechten aan het natuurgebied Weerribben-Wieden en aan het label Nationaal Park. Het gevaar is echter dat de respons van de niet-bezoekers te groot zou worden in het gehele onderzoek en er dan te weinig respondenten in de steekproef zouden zitten die wel de Weerribben-Wieden hebben bezocht. Bovendien zou het onderzoek dan meer een nationale focus hebben over het label Nationaal Park in het algemeen en niet zo zeer over de Weerribben-Wieden gaan. Tevens was een belangrijke afweging om voldoende budgettaire data te kunnen verzamelen van de bezoekers. De steekproef bestaat dus uit personen uit het gehele GfK panel, die hebben aangegeven het natuurgebied Weerribben-Wieden te hebben bezocht in de afgelopen 12 maanden. Dit waren 1650 personen. Er is bewust voor gekozen om niet het label Nationaal Park te noemen omdat dit één van de vervolgvragen was. Deze 1650 personen zijn benaderd voor een vervolgonderzoek. Het veldwerk vond plaats tussen 15 en 20 december 2016. Uiteindelijk heeft het een respons opgeleverd van 1116 personen, ofwel 68\%. De antwoorden zijn representatief gemaakt voor Nederland op basis van een weging op geslacht, leeftijd, opleiding en provincie op randtotalen.

De vragen over stellingen en de recreatieactiviteiten zijn randomized gesteld. Dat wil zeggen dat telkens een andere volgorde van de stellingen en activiteiten wordt aangeboden aan een respondent. Dit voorkomt een zekere mate van selectie dat de eerste stelling steeds de hoogste score krijgt.

Er is tevens een Engelstalige en Duitstalige versie gemaakt van de vragenlijst. Deze zouden met de Nederlandse versie worden verspreid onder de klanten van een aantal leden van de begeleidingscommissie. Deze actie is niet doorgegaan door tijdgebrek.

De vragenlijst van het online onderzoek is met de begeleidingscommissie besproken en vastgesteld. De vragen zijn geanalyseerd met SPSS waarbij de descriptieve ANOVA F-test en correlatietesten zijn gebruikt om te onderzoeken of er significante verschillen bestaan tussen antwoorden op de vragen. De post-hoc test Bonferroni Alpha is gebruikt om te onderzoeken of er tussen groepen verschillen bestaan. Bij deze test is het verschil significant bij een $\mathrm{p}$-waarde van lager dan 0,05 zodat de uitspraken met een zekerheidsmarge van 95\% kunnen worden gedaan. 


\section{Resultaten uit de literatuur}

\section{$2.1 \quad$ Inleiding}

Onderzoek naar de toegevoegde waarde van natuurgebieden is niet nieuw. Lastiger wordt het wanneer gezocht wordt naar informatie over de betekenis van een label voor een gebied. Er zijn diverse labels die natuurgebieden kunnen dragen zoals Nationaal Park, UNESCO World Heritage, Natura2000-gebied, GEO-parcs etc. In dit hoofdstuk wordt een beperkt overzicht gegeven van de huidige kennis over de betekenis van een label voor natuurgebieden, met een focus op Nationale Parken. De informatie is afkomstig uit (inter) nationaal onderzoeken. Onderdeel van de studie zal zijn in hoeverre een label invloed heeft op het bezoek aan een Nationaal Park. Voordat bezoekers een bestemming bezoeken speelt het mentale beeld dat mensen hebben van een bestemming (het destination image) al een rol in het keuzeproces (Govers, Go \& Kumar, 2007; Beerlí \& Martin, 2004). Dit mentale beeld is gebaseerd op eerdere ervaringen van de persoon, ervaringen die men hoort van anderen en beelden uit de media (bijvoorbeeld het internet, de televisie of reisgidsen). Het eerste contact dat een bezoeker heeft met een bestemming is dan ook niet met de bestemming zelf, maar een representatie hiervan (Reinius \& Fredman, 2007) via een marker van het gebied waarmee een bepaalde kennis wordt opgedaan. Een marker kan informatie over een gebied zijn, een naam, een concept of een image of slechts een idee. Dit gegeven is belangrijk indien men nieuwe bezoekers wil aantrekken. Dit onderdeel is voor het Nationaal Park Weerribben-Wieden al uitgevoerd in de vorm van een customer journey door studenten van Stenden Hogeschool.

Eagles (2001) en Nolte (2004) stellen dat het label Nationaal Park bij veel mensen een bekend merk is en meer bekend dan andere labels zoals World Heritage. Deze bekendheid kan meehelpen bij de beslissing tot een mogelijk bezoek.

Het daadwerkelijk bezoeken van een gebied geeft een bepaalde beleving en zal gevoelens bij de bezoeker opwekken over dat gebied. Een gebied krijgt daardoor een bepaalde betekenis voor mensen ofwel bepaalde sociaal-emotionele waarden. Deze waarden kunnen ook optreden bij geen bezoek, maar in dit onderzoek willen we meer de mate van sociaal-emotionele waarden van de bezoekers peilen. De reden hiervoor is dat indien zij hoge sociaal-emotionele waarden hebben bij het Nationaal Park Weerribben-Wieden, zij dan een soort ambassadeursrol kunnen spelen en op deze wijze mogelijk het beslissingsproces van anderen om een bezoek te brengen kunnen beïnvloeden. De aanname is dat niet-bezoekers daarin een andersoortige rol spelen. Met een soort ambassadeursrol van de bezoeker kan de toegevoegde waarde stijgen.

Vaak gaat het bezoeken van een gebied gepaard met bepaalde bestedingen die in en rond het gebied worden gedaan. Dit levert een economische waarde op.

Uit de (internationale) literatuur is bekend dat de toegevoegde waarde te verdelen is in:

- Sociaal-emotionele waarde.

- Economische waarde.

\subsection{Sociaal-emotionele waarde}

Een marker zoals een label levert dus een bepaalde kennis over een natuurgebied op en daarmee krijgt het gebied een bepaalde waarde voor mensen. In de literatuur wordt een onderscheid gemaakt tussen use- value en non-use value, ofwel gebruikswaarde en niet-gebruikswaarde. De gebruikswaarde is de mate waarin het natuurgebied daadwerkelijk gebruikt wordt en hoe vaak. Hoe meer bezoekers en hoe meer herhalingsbezoek hoe hoger de gebruikswaarde. Vaak gaat dat gepaard met een hogere affiniteit. Shamai (1991) beschrijft de affiniteit van mensen met een gebied via de 
mate waarop mensen voelen dat ze deel uitmaken van een gebied, de mate van betrokkenheid met het gebied en de mate van verbondenheid met het gebied. Arnberger et al. (2012) stellen dat deze affiniteit van mensen met beschermde natuurgebieden cruciaal is voor het voortbestaan en succes van deze gebieden. Het succes is te vergroten wanneer de beheerders zo goed mogelijk inspelen op de affiniteit van de bezoekers.

De niet-gebruikswaarde (Walsh, Loomis \& Gillian; Perman) wordt omschreven als de welvaart die mensen ontlenen aan natuur zonder dat zij er gebruik van maken. Hierbij kan een onderscheid gemaakt worden tussen een bestaanswaarde, een verervingswaarde, een optiewaarde en een altruïstische waarde. De bestaanswaarde is gelijk aan de waarde die de huidige generatie hecht aan het bestaan van een ecosysteem, ongeacht gebruik. De verervingwaarde is de waarde die de mens hecht aan het open houden van de mogelijkheid van toekomstig gebruik door toekomstige generaties. Goossen et al (2007) stellen dat de bestaanswaarde en de verervingswaarde relaties hebben met het tegengaan van vervreemding met de natuur. Vervreemding kan weer tot weinig draagvlak voor natuurbehoud leiden. Onder optiewaarde wordt de waarde verstaan die de mens hecht aan het open houden van de mogelijkheid van toekomstig gebruik door de huidige generatie. De altruïstische waarde is de waarde die mensen hechten aan het feit dat anderen een gebied kunnen bezoeken, zonder dat ze er zelf gebruik van maken.

Uit een onderzoek (Goossen et al, 2007) in Nationaal Park de Hoge Veluwe $(\mathrm{N}=438$ ) en het Haagse Zuiderpark $(\mathrm{N}=343)$ blijkt in beide gebieden dat de niet-gebruikswaarde hoger scoort dan de gebruikswaarde. In het onderzoek is een verschil gemaakt tussen de bezoekers en de niet bezoekers met betrekking tot de bestaanswaarde van beide parken. Er wordt geconcludeerd dat de bestaanswaarde hoog is voor beide parken en bij beide groepen bezoekers. De bestaanswaarde van het Zuiderpark ligt iets hoger ( bij beide groepen bezoekers) dan het Nationaal Park de Hoge Veluwe. Met de stelling over de optiewaarde zijn de Haagse bezoekers het gemiddeld genomen iets meer eens dan de bezoekers van het Nationaal Park de Hoge Veluwe. Dit geldt ook voor de verervingswaarde. De verbondenheid met het gebied scoort in beide parken lager dan de gebruiks- en niet-gebruikswaarde. De verbondenheid met het Zuiderpark is echter weer sterker dan de verbondenheid met het Nationaal Park de Hoge Veluwe. Als reden hiervoor wordt genoemd dat dit park in de stad ligt.

Ook uit een studentenonderzoek (Capel et al, 2007) in het Nationaal Park Zuid-Kennemerland onder bezoekers $(\mathrm{N}=41)$ en niet-bezoekers $(\mathrm{N}=11)$ blijkt dat de niet-gebruikswaarde (waarbij de optiewaarde voor de bezoekers het belangrijkst is en de bestaanswaarde voor de niet-bezoekers) net iets belangrijker wordt gevonden dan de gebruikswaarde die weer hoger scoort dan de verbondenheid met het Nationaal Park.

Uit deze onderzoeken blijkt dat de niet-gebruikswaarde niet uitsluitend geldt voor niet-bezoekers, maar dat ook bezoekers hier een waarde aan hechten.

Borrie, Freimund \& Davenport (2002) stellen dat de sociaal-emotionele waarden belangrijk zijn voor het vergroten van het ecologisch en economisch belang. Het draagvlak voor het behoud en bescherming van natuurgebieden kan ermee worden vergroot.

\subsection{Economische waarde van een label}

Wanneer mensen een natuurgebied bezoeken, worden er veelal bestedingen gedaan. Daarmee is er ook een economische waarde die dus sterk gekoppeld is aan de gebruikswaarde. Een recentelijke modelberekening (Schägner et al, 2016) schat dat alle Nationale Parken in Nederland een jaarlijkse omvang hebben van 93 miljoen bezoeken. De economische waarde van alle Nationale Parken in Nederland wordt geschat op 667 miljoen euro. Het is dan van belang om te onderzoeken of de bezoeken worden gemaakt omdat het een aantrekkelijk gebied is zoals de Weerribben-Wieden, of dat dit komt omdat het gebied het label 'Nationaal Park' draagt of misschien zijn beide zaken van belang.

Uit een onderzoek (Cumulus Consultants \& ICF GHK, 2013) in Engeland onder vijf Nationale Parken blijkt dat meer dan 50 procent van de bedrijven in de omgeving van een Nationaal Park het idee 
hadden dat hun omzet direct of indirect het gevolg was van de hoge kwaliteit van het natuurgebied en dat het label 'Nationaal Park' een positieve bijdrage levert. Dit percentage is hoger voor bedrijven met relaties met toerisme zoals hotels met 89 procent en detailhandel met 69 procent.

Uit een studie (SQW, 2006) in drie Nationale Parken in Engeland blijkt dat 26 procent van de bedrijven in de aangrenzende dorpen en steden het idee hadden dat de status van Nationaal Park belangrijk was om nieuwe bedrijven te lokken. Het label werkt volgens hen als een 'pull-factor' voor bedrijven.

Carlsen \& Wood (2004) stellen dat Nationale parken een significante bijdrage leveren aan de economie van lokale regio's en aangrenzende dorpen en/of steden door middel van toeristische uitgaven. Een onderzoek (Goossen et al, 2007) in Nationaal Park de Hoge Veluwe onderschrijft dit want het blijkt dat de gemiddelde bestedingen per bezoeker $€ 15$,- in het park is (exclusief entreeprijs) en $€ 19$,- buiten het park. Een goede kwaliteit van de natuurlijke omgeving kan leiden tot een hogere waardering van het Nationaal Park en zo ook van het label in het algemeen. Het label kan er op deze manier voor zorgen dat er meer mensen naar het gebied komen, wat mogelijk resulteert in een betere geldstroom (Triple E, 2010).

In het onderzoek naar het Cairngorms National Park (Progressive, 2015) hebben onderzoekers de bezoekerspopulatie ingedeeld in: bewoner, dagbezoeker, korte verblijvers en lange verblijvers. Hieruit blijkt dat in het Schotse park tijdens een langdurig verblijf het meest wordt uitgegeven $(169,16$ euro), gevolgd door de dagbezoeker (20,18 euro) en door bewoners het minste $(18,10$ euro).

De gemiddelde besteding per bezoeker in een gezelschap tijdens het bezoek aan de Drentsche AA (AMG, 2016) is 17.60 euro. Zonder verblijfskosten mee te nemen, is er een bedrag van gemiddeld 11.41 euro per bezoeker. Gemiddeld worden de hoogste uitgaven gedaan aan overnachtingen en de meeste uitgaven aan horeca-bezoek. De meeste uitgaven worden door toeristen gedaan: voor horecabezoek is dit gemiddeld $€ 10,99$ en voor overnachting $€ 17.11$ per persoon. Bezoekers die de Drentsche Aa nog nooit eerder of niet vaak hebben bezocht geven gemiddeld meer uit dan bezoekers die het gebied vaker bezoeken.

Om de economische meerwaarde van een bezoek te toetsen moet dus bekend zijn in welke mate de voorziening relevant is voor het bezoek. Klijs \& Korteweg Maris(2014) stellen dat het voor het bepalen van de economische waarde belangrijk is om een onderscheid te maken tussen bewoners,

dagbezoekers en verblijfstoeristen.

Uit onderzoek (Bade et al, 2008) blijkt dat het gebied Weerribben-Wieden een positieve economische impact op de regio heeft.

Daams (2016) concludeert dat aantrekkelijke natuurgebieden de prijzen van woningen over een afstand tot wel $7 \mathrm{~km}$ opstuwt. Het benoemen van een gebied tot Nationaal Park heeft een waarde toevoegend effect. Woningen in een groene omgeving zijn 4 tot $30 \%$ meer waard dan hetzelfde type woningen in een niet-groene omgeving. Volgens makelaars stijgen de huizenprijzen met 3 tot $5 \%$ bij de benoeming tot Nationaal Park (Triple E, 2010).

\subsection{Effecten van het label}

Weiler en Seidl (2004) zagen een toename in bezoek in acht gebieden in de Verenigde Staten nadat het label Nationaal Park was toegekend. Fredman et al (2005) hebben het bezoek voor en na toekenning van het label Nationaal Park onderzocht voor een natuurgebied in Zweden en constateren een toename van $40 \%$ in het bezoek. In een onderzoek naar World Heritage gebieden in OECD-landen in 1998, bleek dat na toekenning van het label een toename werd gerapporteerd van het bezoek met jaarlijks 1-5\% (Hall and Piggin 2001).

Buckley (2002) heeft een uitgebreide studie gedaan naar de effecten van het label World Heritage op het bezoek aan Heritage gebieden in Australië. Hij concludeert dat het moeilijk is om het effect van het label te achterhalen omdat er te weinig data zijn om te onderbouwen of het label een toegevoegde 
waarde heeft. Voor enkele World Heritage gebieden waar wel voldoende data waren, constateert hij dat het label een positief effect heeft op de toeristische bestedingen, vooral omdat die gebieden relatief veel buitenlandse bezoekers trekken.

Reinius \& Fredman (2007) hebben in Zweden voor Nationale Parken, World Heritage gebieden en natuurreservaten onderzoek gedaan naar de werking van het label op het bezoek. Ze concluderen dat de beschermde status belangrijk is voor toeristen en voor $44 \%$ van invloed is op hun beslissing om het gebied te bezoeken. De labels functioneren als toeristische markers. Het label Nationaal Park heeft een grotere invloed met betrekking tot bezoek op toeristen dan de labels World Heritage gebieden en natuurreservaten. Voor buitenlandse toeristen geldt dit nog meer dan voor binnenlandse toeristen. Dit komt overeen met wat Weiler en Seidl (2004) stellen dat buitenlandse toeristen eerder komen door de status van Nationaal Park dan lokale toeristen die andere motieven, dan de status van beschermd gebied, hebben om een gebied te bezoeken. Ook het onderzoek naar bezoek in het Cairngorms National Park (Progressive, 2015) laat zien, dat de status van Nationaal Park vooral bij buitenlandse toeristen een rol (63\%) speelt, ten opzichte van binnenlandse toeristen (39\%). Uit het onderzoek van Richards (2002) blijkt dat diegene die verder weg wonen van een natuurgebied, zich meer concentreren op 'must-see' gebieden omdat het bezoek meer voorbereiding vraagt in tijd en geld. Reinius \& Fredman (2007) concluderen dat de status van Nationaal Park minder van belang is bij toeristen die vaak het natuurgebied bezoeken.

Uit een onderzoek van Folmer (2016) blijkt echter dat de Waddenzee nog maar weinig profiteert van de Werelderfgoedstatus die het gebied in 2009 kreeg. Deze status is bij de grote meerderheid (76\%) van de bezoeker wel bekend en die bekendheid is de afgelopen jaren gegroeid. De Waddenzee zelf als mooi natuurgebied speelt voor een kleine zestig procent een reden voor een bezoek aan het gebied. Een klein deel van de 434 ondervraagde bezoekers $(6,5 \%)$ komt speciaal voor de status van Werelderfgoed naar het Waddengebied.

Uit een representatieve steekproef onder de Nederlandse bevolking (Goossen \& de Boer, 2006) blijkt dat voor 33\% de status van Nationaal Landschap het landschap in de woonomgeving meerwaarde geeft. Voor $45 \%$ van de Nederlanders heeft de status geen meerwaarde en $22 \%$ is neutraal.

Uit de resultaten van een studentenonderzoek in Nationaal Park Drentsche AA (AMG, 2016) blijkt dat 73\% van de 86 bezoekers weet dat de Drentsche Aa een Nationaal Park is, waarbij twee derde van die groep echter aangeeft dat dit geen of nauwelijks een rol heeft gespeeld in het bezoeken van het gebied. Verder speelt het Nationaal Park label een grotere rol voor bewoners die het gebied al een langere tijd bezoeken. Verder is gebleken dat het overgrote deel van de respondenten het label Nationaal Park verbindt aan behoud van de natuur. Een klein percentage ( $5 \%$ ) van de bezoekers geeft aan dat ze niet de Drentsche Aa zouden bezoeken als het geen Nationaal Park zou zijn. Dit percentage ligt in vergelijking met andere studies naar de invloed van het label Nationaal Park lager. In het onderzoek van Arnberger et al. (2012) is bijvoorbeeld gevonden dat $12 \%$ van de ondervraagden niet naar het Gesaeuse Nationaal Park in Oostenrijk zou komen als het geen Nationaal Park was. In beide gevallen zou de overgrote meerderheid dus ook het natuurgebied bezoeken als het niet het label Nationaal Park zou dragen.

Ondanks dat bezoekers veelal niet naar de Drentsche AA kwamen omdat het een Nationaal Park is, hechten zij toch relatief veel waarde aan het voortbestaan van Nationale Parken. De hoofddoelstellingen van het label Nationaal Park - namelijk het behoud van de natuur en het bieden van recreatiemogelijkheden - vinden de meeste bezoekers belangrijk. Dit resultaat is ook gevonden in het Gesäeuse National park (Arnberger et al., 2012), waarbij meer dan 90\% van de respondenten het ermee eens was dat de hoofdtaken van een nationaal park 'het behoud van het natuurgebied' en 'het bieden van recreatiemogelijkheden van een hoge kwaliteit' zijn.

In het onderzoek in de Drentsche AA (AMG, 2016) wordt gesteld dat het mogelijk is dat bezoekers zich niet per se bewust zijn van het label, maar indirect het behoud ervan en waar het label voor staat wel degelijk belangrijk vinden. Men hecht veel waarde aan het voortbestaan en de bescherming van natuurgebieden die gelabeld zijn als Nationaal Park, al komen ze niet specifiek omdat het natuurgebied een label draagt. 
De conclusie is dat de literatuur geen eenduidig beeld geeft van het effect van het dragen van het label Nationaal Park op het bezoek, maar dat het label wel gepaard gaat met diverse waarden. 


\section{De bezoeker van het Nationaal Park Weerribben-Wieden}

\section{$3.1 \quad$ Inleiding}

In dit hoofdstuk bespreken we de resultaten van de kenmerken van de bezoeker aan het Nationaal park Weerribben-Wieden. Het gaat hierbij om inzicht in de gebruikswaarde van het natuurgebied Weerribben-Wieden. Door het bezoek te meten kan bepaald worden wat de gebruikswaarde is. Daarnaast leveren de gegevens interessante wetenswaardigheden op over het hoe en door wie het gebied wordt bezocht en wat hun oordeel over het natuurgebied is. In het kort worden de achtergrondkenmerken van de bezoeker beschreven. Het betreft uitsluitend bezoekers uit Nederland. Ook beschrijven we zijn mening over het Nationaal Park en zijn ondernomen recreatieactiviteiten en bestedingen en het gezelschap waarmee hij/zij meestal een bezoek brengt aan het Nationaal park Weerribben-Wieden. Zoals eerder is aangegeven is een bezoeker iemand van 18 jaar of ouder die in de afgelopen 12 maanden het natuurgebied de Weerribben-Wieden heeft bezocht. Zoals uit het vorige hoofdstuk blijkt, is het zinnig om een onderscheid te maken tussen diverse type bezoeker:

- $\quad$ bezoekers wonend in of nabij een Nationaal Park;

- $\quad$ dagbezoekers uit heel Nederland;

- $\quad$ verblijfstoeristen die een accommodatie huren in en rond het Nationaal Park.

\subsection{Type bezoeker}

Bezoekers die dicht bij het Nationaal Park wonen, hebben wellicht een ander gebruik van het park en andere meningen over het label dan andere bezoekers. Daarnaast kan een verschil worden gemaakt tussen dagbezoekers en toeristen die in de buurt overnachten en een vakantie in of nabij het Nationaal Park houden. Hun beslissing is mogelijk eerder gemaakt en wellicht met andere redenen dan de dagbezoeker die de beslissing minder voorbereid. Vandaar dat, in navolging van de resultaten uit het literatuuronderzoek, een onderscheid wordt gemaakt naar bewoner, dagbezoeker en toerist. Een bewoner woont in de nabijheid ${ }^{2}$ van het Nationaal Park en zal voor zijn uitstapjes het park dichtbij kunnen vinden. Door die nabijheid zal de bewoner misschien vaker het park bezoeken. Een dagbezoeker woont verder weg en zal dus meer moeite moeten doen om het Nationaal Park te bezoeken, maar hij maakt in de buurt geen overnachting. Dat doet een toerist wel en zal tijdens zijn/haar verblijf het Nationaal Park bezoeken. Uit Tabel 1 blijkt uit het online-onderzoek dat het merendeel (52\%) van de bezoekers als dagbezoeker kan worden bestempeld, gevolgd door toeristen $(35 \%)$ en ten slotte bewoners (13\%).

Tabel 1 Type bezoeker.

\begin{tabular}{lrr} 
Type & N & Percentage \\
Bewoner & 148 & 13 \\
\hline Dagbezoeker & 579 & 52 \\
\hline Toerist & 389 & 35 \\
\hline Totaal & 1116 & 100 \\
\hline
\end{tabular}

\footnotetext{
2 De gemeenten Steenwijkerland, Meppel, Westerveld, Weststellingwerf, Zwartewaterland, Staphorst en Noordoostpolder zijn als dichtbij gedefinieerd
} 
Van de bewoners komt het merendeel (38\%) uit de gemeente Steenwijkerland, gevolgd door Meppel ( $17 \%)$, de Noordoostpolder (16\%) en Weststellingwerf (11\%). Relatief minder woont de bewoner in de gemeenten Zwartewaterland, Staphorst of Westerveld (Tabel 2).

Tabel 2 Verdeling bezoekersgroep 'bewoners' per gemeente.

\begin{tabular}{lrr} 
Type & N & Percentage \\
Steenwijkerland & 56 & 38 \\
\hline Meppel & 25 & 17 \\
\hline Noordoostpolder & 24 & 16 \\
\hline Weststellingwerf & 16 & 11 \\
\hline Zwartewaterland & 11 & 7 \\
\hline Staphorst & 8 & 5 \\
\hline Westerveld & 8 & 5 \\
\hline Totaal & 148 & 100 \\
\hline
\end{tabular}

De dagbezoeker komt vooral uit Overijssel en de noordelijke drie provincies (Figuur 1). Bijna de helft (49\%) komt daar vandaan. Opvallend is dat de toeristen met $11 \%$ daar relatief minder vaak wonen, maar juist in de andere provincies. De provincies Zuid- en Noord-Holland en Noord-Brabant zijn de grootste leveranciers van toeristen voor Nationaal Park de Weerribben-Wieden, respectievelijk 23\%, $16 \%$ en $17 \%$. Het blijkt dat de bezoeker overal vandaan komt. Circa een derde (34\%) van alle bezoekers woont binnen een straal van $50 \mathrm{~km}$ van het Nationaal Park Weerribben-Wieden.

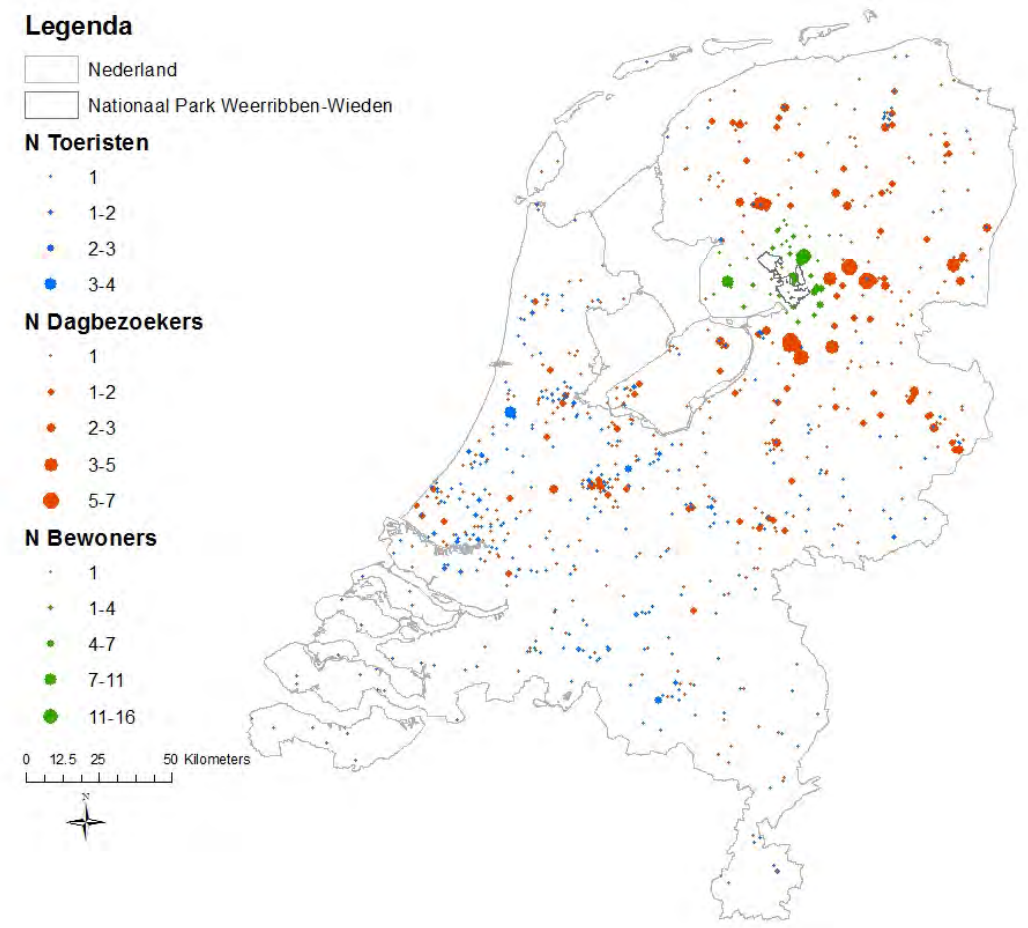

Figur 1 Verdeling woonplaats van type bezoekers per 4-positie postcode.

De toeristen verblijven het meest in Giethoorn (22\%) en Giethoorn is dan ook de belangrijkste leverancier van toeristen die een bezoek brengen aan het Nationaal Park. Steenwijk staat op de tweede plaats met $11 \%$ en Paasloo met $8 \%$. Ossenzijl en Blokzijl volgen met ieder $5 \%$. De meeste toeristen verblijven op de camping (28\%), gevolgd door een hotel $(21 \%)$ of een bungalow in een park $(17 \%)$. Sommige toeristen verblijven in een accommodatie van vrienden/kennissen/familie $(8 \%)$ of 
via Bed and breakfast (7\%). Circa 6\% van de toeristen overnacht in een eigen vakantiewoning (niet op een park) en $4 \%$ op een boot. Een hostel/groepsaccommodatie biedt $4 \%$ van de toeristen een overnachtingsplaats aan en $3 \%$ boekt een kamer/appartement via AirBnB, Couch surfing, wimdu etc. Een pension wordt het minst gebruikt (1\%).

Een ruime meerderheid ( $80 \%$ ) van alle bezoekers bezoekt Nationaal Park Weerribben-Wieden één of enkele keren per jaar (Tabel 3). Maar er zit wel een significant verschil tussen de type bezoekers. In verhouding bezoeken de bewoners en toeristen het park vaker dan de dagbezoekers. Bij de toeristen valt op dat ze tijdens hun vakantie relatief vaak het gebied dagelijks of enkele keren per week bezoeken.

Tabel 3 Frequentie (\%) aan bezoek Weerribben-Wieden per type bezoeker.

\begin{tabular}{lrrrr} 
Type & Bewoner & Dagbezoeker & Toerist \\
Dagelijks/meer keren per dag & 5 & 0 & 2 & 2 \\
\hline 1 of enkele keren per week & 9 & 5 & 10 & 7 \\
\hline 1 of enkele keren per maand & 20 & 10 & 10 & 78 \\
\hline 1 of enkele keren per jaar & 66 & 85 & 390 & 1115 \\
\hline Totaal $\left(\mathrm{N}^{3}\right)$ & 147 & 578 & 80 \\
\hline
\end{tabular}

Het opleidingsniveau is verdeeld naar laag, midden en hoog. De bezoekers scoren het meest op een midden niveau van opleiding. Wel is er en zwakke correlatie met de type bezoeker. In verhouding scoren de dagbezoekers relatief hoger op opleidingsniveau dan bewoners die relatief vaker op een lager niveau scoren. Toeristen zitten er tussen in.

De gemiddelde leeftijd van de bezoeker is 49 jaar. Dagbezoekers zijn iets jonger dan de bewoners en toeristen.

Tabel 4 Gemiddelde leeftijd per type bezoeker.

\begin{tabular}{lr} 
Type & Leeftijd \\
\hline Bewoner & 50 \\
\hline Dagbezoeker & 48 \\
\hline Toerist & 49 \\
\hline Totaal & 49 \\
\hline
\end{tabular}

Mannen (57\%) hebben iets vaker de vragenlijst ingevuld dan vrouwen (43\%). Dit geldt vooral voor de toeristische bezoeker waarvan $62 \%$ man is en iets minder voor de dagbezoeker ( $56 \%$ man). Van de bewoners hebben vrouwen $(51 \%)$ iets vaker de vragenlijst ingevuld.

\subsection{Recreatieactiviteiten}

In het Nationaal Park Weerribben-Wieden is zeer veel te doen. Dat blijkt onder andere uit de tijdsduur die men in het park besteed (Tabel 5). Bijna een derde (32\%) van de bezoekers blijft langer dan 4 uur in het park. Gemiddeld blijft men ongeveer 3 uur in het Nationaal Park.

\footnotetext{
${ }^{3}$ De $\mathrm{N}$ voor type bezoeker is hier anders dan in vorige tabellen omdat hier de weging voor representativiteit is toegepast.
} 
Tabel 5 Tijdsduur (\%) per type bezoeker.

\begin{tabular}{lrrrrr} 
Type & Minder dan 1 uur & $1-2$ uur & $2-3$ uur & $3-4$ uur Langer dan 4 uur \\
Bewoner & 36 & 20 & 18 & 6 \\
\hline Dagbezoeker & 27 & 52 & 48 & 56 & 34 \\
\hline Toerist & 36 & 174 & 34 & 33 \\
\hline Totaal (N) & 22 & & 327 & 240
\end{tabular}

Bewoners blijven significant korter dan dagbezoekers en toeristen. De meerderheid (67\%) van de bewoners blijft niet langer dan 3 uur. Dagbezoekers en toeristen blijven in verhouding langer. Vooral dagbezoekers blijven langer dan 4 uur.

Bij het gezelschap waarmee men het Nationaal Park bezoekt is een tweedeling te zien. Of men komt met een partner of in grotere groepen. De gemiddelde groepsgrootte is dan ook 4,3 personen. Bijna 42 procent van de bezoekers komt met een partner. Met het gezin komt 20 procent en 16 procent komt met de familie het park bezoeken. Het park wordt ook met vrienden aangedaan (12\%). Minder gaat men alleen op pad $(7 \%)$ of met een grote groep bekenden $(2 \%)$ of met een bedrijf/vereniging/school ( $1 \%$ ). Er is een statistisch verband tussen type bezoeker en gezelschap. Bewoners gaan in verhouding vaker alleen op pad dan dagbezoekers en toeristen. Toeristen gaan relatief vaker met partner, vrienden of familie. Dagbezoekers gaan in verhouding vaker met grotere groepen zoals het gezin, of met een grote groep bekenden of met een bedrijf/vereniging/school. Dat blijkt ook uit de gemiddelde groepsgrootte dat uit 5 personen bestaat, terwijl dit voor toeristen gemiddeld 3,6 is en voor bewoners 2,9 .

In het algemeen heeft men niet echt een mening (55\%) of er teveel bezoekers in het Nationaal Park Weerribben-Wieden zijn. Meer dan een kwart (27\%) vindt dat er niet teveel bezoekers zijn; 19\% vindt van wel. Het blijkt dat hoe vaker men het gebied bezoekt, hoe meer men vindt dat er teveel bezoekers zijn.

De recreatieactiviteiten die worden ondernomen zijn veelzijdig (zie Bijlage 1). Wandelen (56\%) en fietsen (37\%) op eigen fiets zijn de meest populaire activiteiten, gevolgd door een bezoek aan een café/restaurant (27\%) of een info/bezoekerscentrum (26\%). Wandelen wordt significant meer gedaan door bewoners. In totaal wandelt 61 procent van de bezoekers; of gewoon wandelen of via meedoen met een wandelexcursie. Bewoners fietsen (op eigen fiets) ook significant meer dan toeristen die in verhouding weer meer fietsen dan dagbezoekers. Circa 44 procent van de bezoekers fietst in het gebied, of op een eigen fiets, of een gehuurde fiets of doet mee aan een fietsexcursie. Opvallend is dat toeristen relatief minder een café/restaurant bezoeken dan dagbezoekers en bewoners. Deze activiteit staat wel in het lijstje met populaire activiteiten, maar toch brengt bijna driekwart (73\%) van de bezoekers geen bezoek aan een café/restaurant.

Zitten/lezen/luieren (17\%), zeilen/motorbootvaren in een gehuurde boot (16\%), meedoen met een vaarexcursie (15\%), kanoën/roeien in een gehuurde boot (15\%), picknicken ( $14 \%)$, natuurstudie/fotograferen/vogels observeren (11\%) en schaatsen (10\%) zijn eveneens populaire recreatieactiviteiten. Het blijkt dat picknicken significant meer wordt gedaan door dagbezoekers dan door toeristen. Bewoners bezoeken significant meer evenementen dan dagbezoekers en toeristen. Schaatsen wordt ook in verhouding meer gedaan door bewoners dan dagbezoekers en toeristen waarbij dagbezoekers significant meer schaatsen dan toeristen.

Bezoekers die het natuurgebied Weerribben-Wieden vaker per jaar bezoeken, gaan significant vaker de hond uitlaten, mountainbiken en wielrennen (allebei in groepsverband), kanoën/roeien en zeilen/motorbootvaren, surfen trimmen/joggen/hardlopen, skaten/skeeleren, paardrijden (al dan niet op een eigen paard), zwemmen, vissen, luieren/zitten/lezen, schaatsen en meedoen aan een wandelof fietsexcursie en tocht met paard en wagen. Over het algemeen dus de meer sportieve activiteiten. Wandelen, zeilen/motorbootvaren en kanoën/roeien in een gehuurde boot worden vaker ondernomen door bezoekers die minder vaak het gebied bezoeken. 
Gemiddeld worden er 3,2 recreatieactiviteiten ondernomen door de bezoekers. Met gemiddeld 3,9 activiteiten ondernemen bewoners significant meer activiteiten dan dagbezoekers die gemiddeld 3,1 activiteiten ondernemen. Toeristen ondernemen in verhouding de minste activiteiten, namelijk 3,0 . Het is ook wel logisch dat bewoners meer activiteiten ondernemen, omdat ze dichter bij wonen en sneller de mogelijkheid hebben om andere activiteiten te kiezen. Dagbezoekers en toeristen zullen eerder met een bepaald doel gaan.

Opvallend is dat in het Nationaal Park Weerribben-Wieden 39 procent van de bezoekers iets huurt om het gebied te bekijken. Dat kan een zeil- of motorboot zijn of een kano, fiets, surfplank of een paard zijn. Voor het huren moet betaald worden en dat levert het bedrijfsleven omzet op. In Tabel 7 is te zien dat er gemiddeld $€ 2,55$ per persoon per dag wordt uitgegeven om iets te huren. Ook doet 23 procent van de bezoekers mee aan een excursie en ook dat levert inkomsten op. Gemiddeld wordt er per persoon per dag bijna $€ 1,00$ besteed aan excursies.

\subsection{Bestedingen}

lets meer dan drie kwart (77\%) van de bezoekers zegt geld te hebben uitgegeven tijdens hun bezoek aan het Nationaal Park de Weerribben-Wieden. Opvallend is dat bewoners in verhouding significant meer aangeven geen geld te hebben uitgegeven (Tabel 6). Er is ook een zwakke relatie tussen het aantal keren dat men het park bezoekt en de bestedingen. Hoe meer men het park bezoekt hoe meer men geen geld uitgeeft.

Tabel 6 Verdeling (\%) besteding per type bezoeker.

\begin{tabular}{lrr} 
Type & Geen besteding & Wel besteding \\
Bewoner & 38 & 62 \\
\hline Dagbezoeker & 23 & 77 \\
\hline Toerist & 17 & 83 \\
\hline Totaal & 23 & 77 \\
\hline
\end{tabular}

De respondenten en het gezelschap waarmee ze een bezoek brengen aan het Nationaal Park hebben in totaal $€ 92.171$,- besteed. De respondenten en hun gezelschap zijn goed voor in totaal 4800 personen. Gemiddeld besteedt een persoon dan $€ 19,20$ per dag in of rond het Nationaal Park Weerribben-Wieden. Dit ligt iets hoger dan in Nationaal Park Drentsche AA waar het $€ 17,60$ is (AMG, 2016). Wanneer de kosten voor overnachtingen niet worden meegenomen is dat $€ 15,63$ (in Drentsche $A A$ is dat $€ 11,41$ ). Deze resultaten zijn dus de directe bestedingen. Deze directe bestedingen leveren vervolgens weer indirecte bestedingen op. Nader onderzoek is nodig om het totaal aan deze indirecte bestedingen uit te zoeken. Uitgaande van 1,5 miljoen bezoekers per jaar (NPWW, 2010), dan zou dit grofweg een omzet genereren van tussen de 29 en 47 miljoen euro aan directe bestedingen. 
Tabel 7 Gemiddelde uitgaven $(€)$ per persoon\# per dag per type bezoeker.

\begin{tabular}{|c|c|c|c|c|}
\hline Type uitgave & Bewoner & Dagbezoeker & Toerist & Gemiddeld \\
\hline Restaurants en cafés & 5,57 & 5,49 & 10,53 & 6,99 \\
\hline Winkels incl. supermarkt & 0,26 & 0,58 & 3,53 & 1,43 \\
\hline Huur van goederen (zoals fiets, fluisterboot, kano etc.) & 2,32 & 2,36 & 3,03 & 2,55 \\
\hline Excursie (vaar, fiets, wandel etc.) & 0,33 & 0,82 & 1,45 & 0,96 \\
\hline Onderhoud en reparatie & 0,26 & 0,02 & 0,20 & 0,10 \\
\hline Brochures / folders/ kaarten & 0,03 & 0,06 & 0,23 & 0,10 \\
\hline Parkeergeld in Weerribben-Wieden/Giethoorn & 0,11 & 0,25 & 0,57 & 0,33 \\
\hline Vervoerskosten & 0,48 & 1,60 & 2,72 & 1,83 \\
\hline
\end{tabular}

\#inclusief personen die niets hebben besteed. * een flink aantal toeristen (44\%) heeft hier geen opgaven over gedaan, vandaar dat hier twee getallen worden gepresenteerd. Het eerste is gebaseerd op alle toeristen; het tweede alleen op toeristen die een opgave hebben gedaan.

Het meest wordt besteed in restaurants en cafés, namelijk gemiddeld bijna $€ 7,00$ per persoon per dag. Dat is inclusief bezoekers die geen geld hebben uitgegeven ${ }^{4}$. In Bijlage 2 staan de bestedingen exclusief diegene die geen geld hebben uitgegeven. Toeristen geven twee keer zoveel uit in de horeca dan bewoners en dagbezoekers. Dit ondanks het feit dat uit het vorige paragraaf bleek dat toeristen in verhouding minder horeca bezoeken. Alle kopjes koffie en biertjes die het hele jaar door worden genuttigd door de bewoners en dagbezoekers leveren gemiddeld dus minder op dan die paar keer dat toeristen de horeca bezoeken. Absoluut kan dat natuurlijk anders zijn, want zoals uit het paragraaf 3.2 bleek, bezoeken bewoners vaker het natuurgebied. Het is dan ook interessant om de absolute omvang van de bewoners, dagbezoekers en toeristen te onderzoeken.

Ook wordt relatief veel besteed aan overnachting, huur van goederen, vervoerskosten en winkels. Relatief veel respondenten die als toerist worden gekenmerkt, hebben geen opgave gedaan (44\%) over hun bestedingen aan overnachtingen. Vandaar dat er gemiddeld circa $€ 12$,- per persoon per nacht aan overnachting wordt besteed. Als deze toeristen zonder opgaven over hun bestedingen aan overnachtingen niet worden meegerekend, dan blijkt dat er gemiddeld circa $€$ 25,- per persoon per nacht aan overnachting wordt besteed.

Er is een duidelijk verschil tussen type bezoeker. Toeristen geven gemiddeld meer uit (ook als de kosten voor overnachting niet worden meegeteld) dan dagbezoekers die gemiddeld weer iets meer besteden dan de bewoners. Toeristen geven gemiddeld twee keer zoveel meer uit dan bewoners en dagbezoekers. Ook in Nationaal Park Drentsche AA zijn het de toeristen die het meest uitgeven (AMG, 2106) met eveneens $€ 11$ per persoon aan horeca en $€ 17,11$ aan overnachting. Toeristen geven gemiddeld ook meer uit aan de diverse typen uitgaven dan dagbezoekers en bewoners (met uitzondering voor uitgaven aan onderhoud en reparatie). Dagbezoekers besteden op hun beurt gemiddeld meer aan bijna alle type uitgaven (met uitzondering voor uitgaven in horeca en aan onderhoud en reparatie) dan bewoners. Bewoners geven dus in vergelijking met de andere type bezoekers relatief het meest uit aan onderhoud en reparatie.

${ }^{4}$ Dit gegeven is nuttig om de omvang van het economisch belang te bepalen. Het gemiddelde bedrag kan dan aan deze omvang gekoppeld worden, zonder eerst een selectie te maken en de daarvoor benodigde data te verzamelen 


\subsection{Waardering}

Het gemiddelde rapportcijfer voor de waardering van het Nationaal Park Weerribben-Wieden is een 8,2 . Slechts $1 \%$ van de bezoekers geeft een onvoldoende. Er is wel een significant verschil in waardering tussen de type gebruiker. De bewoners waarderen met een gemiddeld rapportcijfer van een 8,55 het gebied hoger dan toeristen $(8,18)$ en dagbezoekers $(8,16)$.

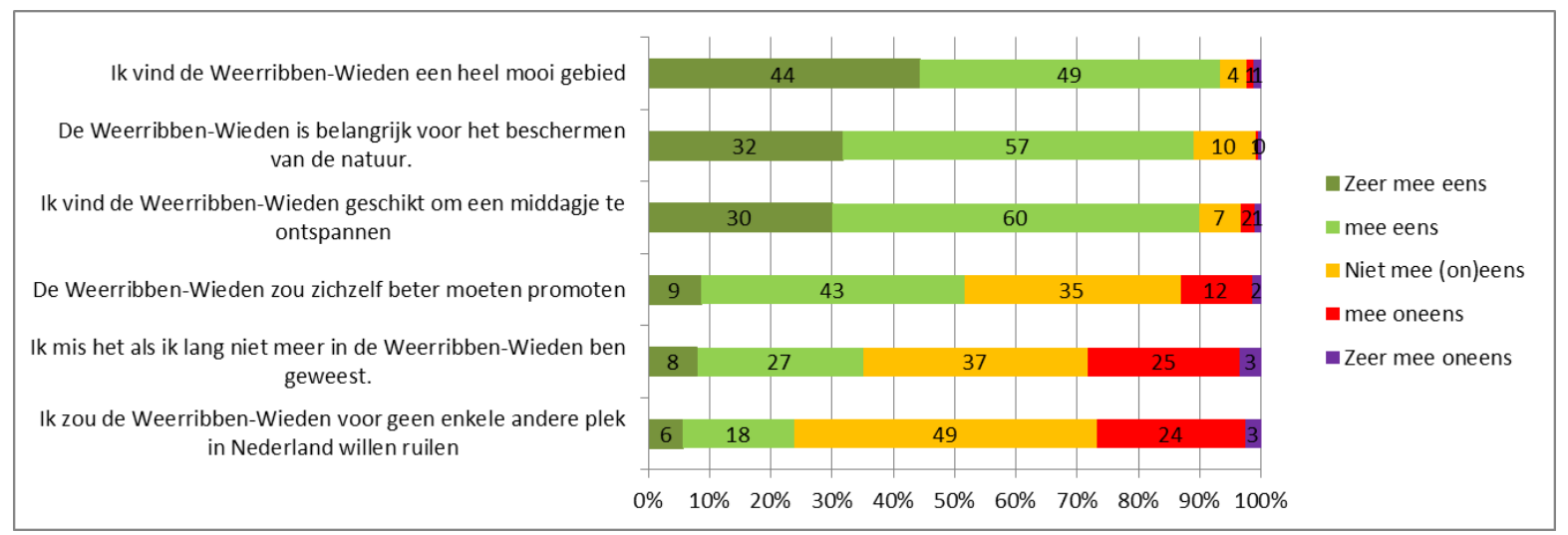

Figuur 2

Mate (\%) van overeenstemming met de stellingen

Een meerderheid van de bezoekers is het er (zeer) mee eens dat de Weerribben-Wieden een heel mooi gebied is ( $93 \%)$, belangrijk is voor het beschermen van de natuur $(87 \%)$, en dat de WeerribbenWieden geschikt is om een middagje te ontspannen (90\%), maar ook dat de Weerribben-Wieden zichzelf beter zou moeten promoten (52\%). Deze gebiedskwaliteiten zijn dus essentieel en instandhouding hiervan is zeer belangrijk voor de sector recreatie en toerisme. Circa $35 \%$ is het zelfs eens met de stelling dat ze de Weerribben-Wieden missen als ze er een tijd niet zijn geweest. Er is geen verschil in opvatting tussen de stellingen en de type bezoeker. Alleen met de stelling 'Ik zou de Weerribben-Wieden voor geen enkele andere plek in Nederland willen ruilen' zijn bewoners het significant meer mee eens dan de andere type bezoekers.

\subsection{Redenen voor bezoek}

Een belangrijk resultaat is dat het voor $24 \%$ van de bezoekers een belangrijke tot doorslaggevende rol heeft gespeeld bij hun beslissing om het gebied te bezoeken dat het een Nationaal Park was. Dit percentage is 25 als alleen de bezoekers worden geselecteerd die weten dat de Weerribben-Wieden een Nationaal Park is.

$\mathrm{Er}$ is echter geen onderscheid gevonden tussen deze vraag en type bezoeker. Wel is er een significante samenhang met hoeveelheid bezoek. Hoe meer men het park bezoekt, hoe belangrijker de rol is dat het gebied een Nationaal Park is. Het lijkt er dus op dat het label 'Nationaal Park' herhalingsbezoek stimuleert. Dagbezoekers en toeristen die vaker het gebied bezoeken vinden het in verhouding ook significant belangrijker dat het gebied een Nationaal park is. Dit zijn dus de vaste gasten ofwel de hardcore van het Nationaal Park. 
Tabel 8 Mate (\%) in hoeverre het een rol heeft gespeeld in beslissing dat het gebied een Nationaal Park is.

\begin{tabular}{lr} 
Rol & Percentage \\
Geen rol & 28 \\
\hline Kleine rol & 17 \\
\hline Rol & 31 \\
\hline Belangrijke rol & 18 \\
\hline Doorslaggevende rol & 6 \\
\hline Totaal & 100 \\
\hline
\end{tabular}

Maar andere redenen die een rol hebben gespeeld bij de beslissing om het gebied te bezoeken zijn belangrijker dan het feit dat gebied een Nationaal Park is (met uitzondering van de redenen leren over cultuur en hond uitlaten). De belangrijkste zijn rust en ontspanning en om gezellig tijd door te brengen met gezin / vrienden / familie (Figuur 3). Maar ook om iets te leren over de natuur is een belangrijke reden evenals om Giethoorn te zien en dan gelijk het Nationaal Park mee te nemen in het bezoek. Meer pragmatische redenen zijn er ook zoals omdat men hier vaker komt, dicht bij woont of (in mindere mate) om de hond uit te laten.

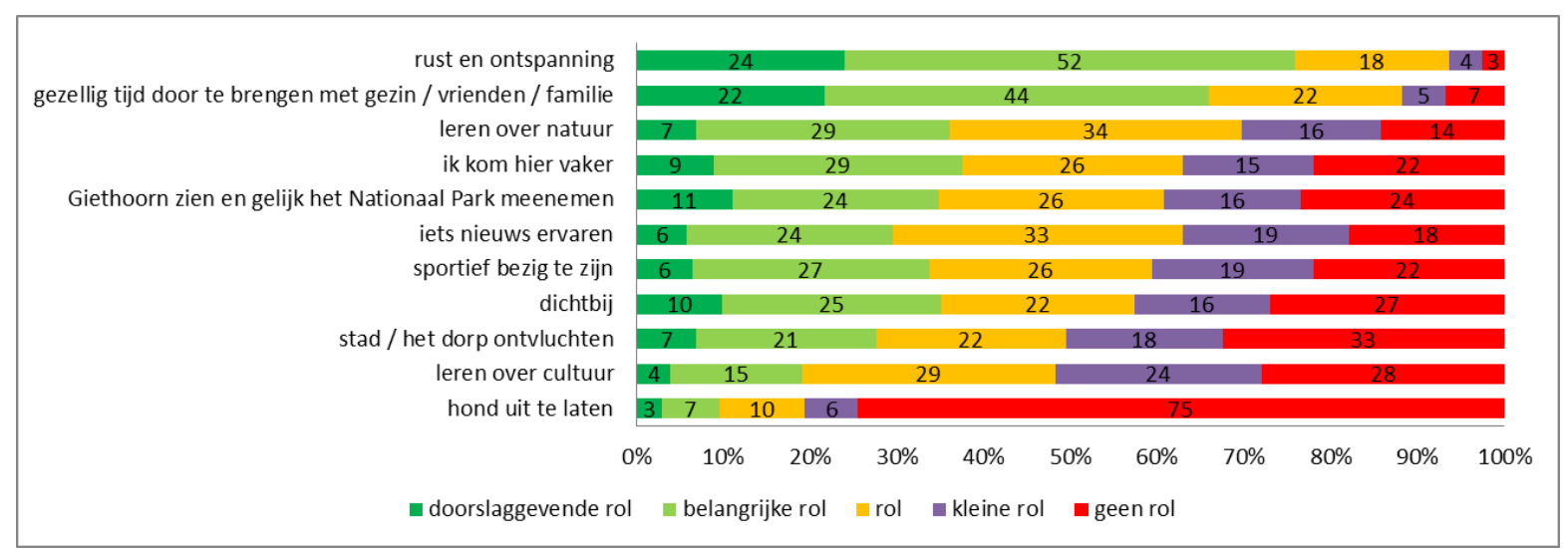

Figuur 3 Rol (\%) bij beslissing om Weerribben-Wieden te bezoeken

Er zijn veel positieve relaties gevonden tussen de redenen (behalve de reden van gezelligheid waar geen correlatie met de frequentie is) en hoe vaak men het gebied bezoekt. Voor rust en ontspanning geldt juist dat hoe minder vaak men het gebied bezoekt, hoe belangrijker deze reden is. Deze relatie is significant, maar zeer zwak. De sterkste samenhang is gevonden tussen de redenen hond uitlaten, vaker komen en dichtbij. Hoe belangrijker deze reden, hoe meer men het gebied bezoekt.

Bewoners noemen in verhouding vaker het motief van rust en ontspanning dan dagbezoekers en toeristen. Het vaker komen en dat het gebied dicht bij is, wordt ook in verhouding meer door bewoners genoemd dan dagbezoekers en toeristen. Het argument van dicht bij wordt relatief vaker genoemd door dagbezoekers dan door toeristen. Toeristen noemen in verhouding vaker het motief om iets nieuws te ervaren dan dagbezoekers (die dat weer meer noemen dan) en bewoners. Toeristen noemen de motieven om te leren over natuur, cultuur en Giethoorn te zien en gelijk het Nationaal Park meenemen, vaker dan dagbezoekers en bewoners. Ze noemen het argument om de stad / het dorp te ontvluchten ook relatief meer dan bewoners. Dagbezoekers hebben in verhouding vaker het motief om familie en vrienden te zien genoemd dan toeristen.

Er zijn veel meer redenen genoemd in de open vraag. In totaal zijn er meer dan 200 diverse redenen genoemd om een bezoek te brengen aan de Weerribben-Wieden (zie Bijlage 3). De belangrijkste redenen zijn dat het een mooi en prachtig gebied is, de natuur, de rust en voor de ontspanning. Maar ook dat het dichtbij is omdat men in de buurt woont, wordt relatief vaak genoemd. Opvallend zijn ook de nostalgische redenen zoals dat men vroeger er vaak kwam met de ouders of er heeft gewoond. 
Ook het bezoek aan familie, vrienden en kennissen zijn redenen om er te komen. Gezelligheid wordt dan ook vaak genoemd. Vandaar dat circa 35\% ook aangeeft Weerribben-Wieden te missen als ze er een tijd niet zijn geweest.

In het algemeen geniet men en men vindt het een leuk gebied om bijvoorbeeld te fietsen of te varen. 


\section{$4 \quad$ De waarden van het label Nationaal Park}

\subsection{Inleiding}

Zoals eerder gesteld zijn de waarden van het label te verdelen in:

- Sociaal-emotionele waarden.

- Economische waarden.

Sociaal-emotionele waarden zijn belangrijk om draagvlak voor het natuurgebied te behouden of te versterken. Naast de gebruikswaarde (het daadwerkelijk bezoeken) zijn er ook de nietgebruikswaarden die invloed kunnen hebben op het draagvlak.

De economische waarden vertalen zich vooral in de bestedingen van bezoekers en hiermee gepaard gaande omzet van bedrijven in en om het natuurgebied.

In dit hoofdstuk worden de waarden van het label beschreven. Om dit te kunnen onderzoeken moeten bezoekers wel weten dat de Weerribben-Wieden een Nationaal Park is. Van de bezoekers zegt $83 \%$ te weten dat de Weerribben-Wieden een Nationaal Park is, $7 \%$ zegt dat het geen Nationaal Park is en $10 \%$ geeft aan het niet te weten.

\subsection{Betekenis label 'Nationaal Park' in het algemeen}

De respondenten zijn gehecht aan de Nederlandse Nationale Parken. Van de respondenten zegt $81 \%$ het (zeer) met de stelling eens te zijn dat het jammer zou zijn als Nederland geen Nationale Parken meer zou kennen. Slechts $4 \%$ is het daar (zeer) mee oneens. Er is geen verschil in opvatting over deze stelling en het type bezoeker. Maar het is de vraag of dit door het label zelf komt, of dat mensen bedoelen dat er geen (beschermde) natuurgebieden meer zouden zijn. Want een meerderheid (55\%) zegt er (zeer) mee eens te zijn dat het voor hem/haar weinig verschil maakt of een natuurgebied een Nationaal Park is of niet, als er maar natuur is. $22 \%$ van de respondenten is het daarmee echter (zeer) oneens. Voor deze mensen heeft het label blijkbaar een toegevoegde waarde. Wat de waarden van het label 'een Nationaal Park' kunnen zijn staat in Tabel 9 weergegeven.

Tabel 9 Betekenis (\%) van het label Nationaal Park ${ }^{5}$ en volgorde van belangrijkheid.

\begin{tabular}{|c|c|c|}
\hline Betekenis & Percentage & Rangorde \\
\hline Het natuurgebied heeft een beschermde status & 64 & 1 \\
\hline uniek natuurgebied, anders dan andere natuurgebieden, en daarmee een eigen identiteit heeft & 51 & 2 \\
\hline het onderhoud aan natuur en toeristische voorzieningen gewaarborgd is & 37 & 4 \\
\hline een soort kwaliteitskeurmerk & 27 & 6 \\
\hline een belangrijke rol voor de aantrekkingskracht van een toeristische regio & 20 & 8 \\
\hline een natuurgebied met goed opgezette toeristische en recreatieve voorzieningen & 18 & 5 \\
\hline uitsluitend bedoeld voor promotie en commercie & 5 & 9 \\
\hline is iets voor het buitenland, want echte natuur hebben we niet in Nederland & 4 & 10 \\
\hline
\end{tabular}

\footnotetext{
${ }^{5}$ Meer antwoorden mogelijk
} 
Voor een meerderheid van de Nederlanders (64\%) betekent het label dat het natuurgebied een beschermde status heeft. Feitelijk is dat onjuist, want juridisch gezien biedt het label de natuur in een Nationaal Park geen beschermde status. Overigens komt dit resultaat overeen met het resultaat van de (inter) nationale literatuur zoals in Zweden (Reinius \& Fredman, 2007), Nationaal Park De Drentsche AA (AMG, 2016) en Motivaction (2016) waarbij het label, volgens de respondenten in alle zes onderzochte landen, staat voor een beschermde status van een natuurgebied.

De definitie van een Nationaal Park dat het een uniek natuurgebied is, anders dan andere natuurgebieden, en daarmee een eigen identiteit heeft, sluit wel goed aan bij de mening van de Nederlanders (51\%). Ook verwacht met dat de overheid betrokken is bij het voortbestaan van het gebied als een natuurgebied (39\%) het label draagt en dat het onderhoud aan natuur en toeristische voorzieningen gewaarborgd is (37\%). Dit komt overeen met de stelling van Eagles. Ongeveer een kwart van de Nederlanders zegt dat het label een soort kwaliteitskeurmerk is ( $27 \%$ ) en bijdraagt aan de bekendheid van het gebied (26\%) en belangrijk is voor de aantrekkingskracht van een toeristische regio (20\%). Dit zijn dus meer promotiedoeleinden hoewel slechts $5 \%$ aangeeft dat het label uitsluitend bedoeld is voor promotie en commercie. Van de Nederlanders verwacht $18 \%$ een natuurgebied met goed opgezette toeristische en recreatieve voorzieningen aan te treffen als het gebied het label draagt. De betekenis van het label dat 'het iets is voor het buitenland, want echte natuur hebben we niet in Nederland', wordt zeer matig onderschreven evenals dat het label 'niets voor mij betekent' (4\%).

Wanneer gevraagd wordt naar de belangrijkste betekenis van het label, dan komt ongeveer dezelfde rangorde naar voren. Alleen dat men verwacht een natuurgebied met goed opgezette toeristische en recreatieve voorzieningen aan te treffen scoort dan iets hoger.

Er is geen verschil in betekenis van het label tussen de typen bezoekers gevonden. Wel is er een zwakke samenhang hoe vaak met het gebied bezoekt en een aantal betekenissen. Wanneer men vaker het gebied bezoekt, onderschrijft men meer dat het natuurgebied een beschermde status heeft, een uniek natuurgebied is, anders dan andere natuurgebieden, en daarmee een eigen identiteit heeft en de overheid betrokken is bij het voortbestaan van het gebied. De matig onderschreven stelling dat het label niets voor mij betekent, wordt in verhouding meer gezegd door bezoekers die het gebied vaker bezoeken. Bezoekt men minder vaak het gebied, dan zegt men in verhouding meer de matig onderschreven stelling dat het label uitsluitend bedoeld is voor promotie en commercie en ook dat het label iets is voor het buitenland, want echte natuur hebben we niet in Nederland.

\subsection{Waarden van het label voor Weerribben-Wieden}

Een meerderheid van de Nederlanders (83\%) weet dat de Weerribben-Wieden een Nationaal Park is, $7 \%$ zegt dat het gebied geen Nationaal Park is en $10 \%$ zegt het niet te weten. Wanneer 'weet niet' en 'nee' worden samengevoegd, dan is er een significant verschil tussen deze kennis en het type bezoeker. Bewoners zijn meer op de hoogte dat de Weerribben-Wieden een Nationaal Park is dan toeristen die weer meer op de hoogte zijn dan dagbezoekers.

Ongeveer 3\% van de Nederlanders geeft aan de Weerribben-Wieden niet te bezoeken als het gebied geen Nationaal Park zou zijn. Van de mensen die weten dat de Weerribben-Wieden een Nationaal Park is, is dit $2 \%$. Dat is dus veel lager dan uit de andere onderzoeken uit de literatuur. Er is geen significant verschil tussen het niet bezoeken en het type bezoeker.

Er zijn niet veel bezoekers (12\%) die het (zeer) eens zijn dat het label 'Nationaal Park' voor de Weerribben-Wieden afgeschaft mag worden. De meerderheid (54\%) is het met deze stelling (zeer) oneens. Een derde (34\%) is het hiermee eens nog oneens. Er is geen significant verschil gevonden tussen het afschaffen van het label en het type bezoeker. Er is wel een verband met de frequentie van het bezoek. Hoe meer men het gebied bezoekt, hoe vaker men het eens is dat het label afgeschaft mag worden. Wellicht komt dit omdat deze bezoekers meer sportieve activiteiten ondernemen waarbij het label minder van belang is. Het is voor deze bezoekers waarschijnlijk belangrijker dat het gebied voldoende mogelijkheden en uitdagingen biedt voor hun sportieve activiteiten. 
De meerderheid van de bezoekers (53\%) vindt dat door het gebied een 'Nationaal Park' te noemen, er extra geïnvesteerd moet worden in de Weerribben-Wieden in natuur en toerisme. Circa $10 \%$ is het hiermee (zeer) oneens. $\mathrm{Er}$ is geen significant verschil gevonden tussen het extra investeren en het type bezoeker. Er is wel een verband met de frequentie van het bezoek. Hoe meer men het gebied bezoekt, hoe vaker men het eens is dat er extra geïnvesteerd moet worden. Bezoekers die aangeven het gebied niet te bezoeken als het geen Nationaal Park zou zijn, zijn ook significant meer eens met deze stelling. Het label roept dus blijkbaar een verwachting op.

\subsection{Sociaal-emotionele waarden}

Het draagvlak voor het behoud en bescherming (dat in de opvatting van Nederlanders de belangrijkste betekenis is van het label Nationaal Park) van natuurgebied Weerribben-Wieden kan worden vergroot als er kennis is welke sociaal-emotionele waarden mensen hebben met het natuurgebied WeerribbenWieden. Het gaat daarbij om de niet-gebruikswaarden (bestaanswaarde, een verervingswaarde, een optiewaarde en een altruïstische waarde), de binding, betrokkenheid en het trots zijn op het gebied.

De bestaanswaarde is onderzocht door de vraag hoe belangrijk het is dat het Nationaal Park Weerribben-Wieden er is, ook als ik er nooit naar toe zou gaan. Een meerderheid is het daar (zeer) mee eens $(81 \%)$ en $4 \%$ is het daar (zeer) mee oneens. Toeristen en bezoekers die minder vaak naar het gebied gaan, zijn relatief meer met deze stelling eens. Een meerderheid (58\%) geeft het ook een goed gevoel dat er dichtbij een Nationaal Park Weerribben-Wieden dat ze kunnen bezoeken. Niet onlogisch is dat bewoners en mensen die relatief vaak het gebied bezoeken meer met deze stelling eens zijn. Dagbezoekers zijn het hier relatief meer mee eens dan toeristen. De bestaanswaarde van het Nationaal Park Weerribben-Wieden is op basis van deze uitkomsten dus hoog te noemen.

De verervingswaarde is ook hoog te noemen. Van de bezoekers zegt $77 \%$ het er (zeer) mee eens te zijn dat bescherming van het Nationaal Park Weerribben-Wieden een plicht is aan onze kinderen. Slechts $3 \%$ is het hiermee (zeer) oneens. Bezoekers die minder vaak het gebied bezoeken, zijn het hiermee in verhouding meer mee eens.

De optiewaarde is eveneens hoog. $86 \%$ is het (zeer) mee eens dat het belangrijk is dat het Nationaal Park Weerribben-Wieden blijft bestaan, zodat ik er ook in de toekomst nog van kan genieten. Ongeveer $2 \%$ is het hiermee (zeer) mee oneens. In verhouding zijn bewoners meer eens met deze stelling dan dagbezoekers en toeristen.

En ook de altruïstische waarde is hoog met $83 \%$ die zegt het belangrijk te vinden dat ook anderen van het Nationaal Park Weerribben-Wieden kunnen genieten. Circa 3\% is het hiermee (zeer) oneens. Vooral bezoekers die niet zo vaak het gebied bezoeken en bewoners zijn het hiermee in verhouding meer mee eens dan toeristen.

Al met al blijkt dus dat de niet-gebruikswaarde hoog is voor het Nationaal Park Weerribben-Wieden. Het gaat vooral om de optiewaarde, de altruïstische waarde, de bestaanswaarde en iets minder de verervingswaarde. 
Ik heb persoonlijke herinneringen aan dit park.

Het park geeft me een gevoel van vertrouwdheid.

Het Nationaal Park Weerribben-Wieden is mijn favoriete plek om te recreëren/ontspannen

Ik identificeer me sterk met het Nationaal Park Weerribben-Wieden

Ik ken allerlei verhalen over dit park.

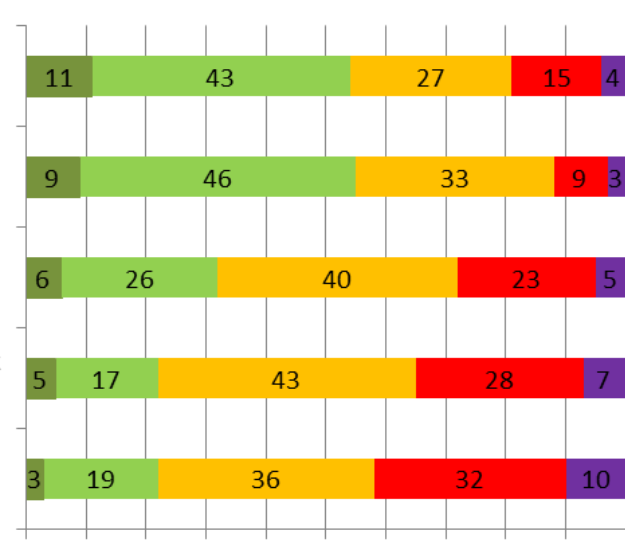

Zeer mee eens

mee eens

Niet mee (on)eens

mee oneens

Zeer mee oneens

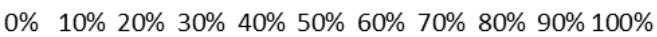

Figuur 4 Mate (\%) van verbondenheid met Nationaal Park Weerribben-Wieden

De affiniteit met het Nationaal Park Weerribben-Wieden komt vooral tot uiting met de verbondenheid en betrokkenheid van de respondenten dat vervolgens al dan niet een gevoel van trots oplevert.

De verbondenheid met het Nationaal Park Weerribben-Wieden komt vooral tot uiting in de stellingen dat het park een gevoel van vertrouwdheid geeft (55\%) en door de persoonlijke herinneringen aan het park $(54 \%)$. Volgens verwachting wordt het gevoel van vertrouwdheid in verhouding vaker genoemd door bezoekers die er vaker komen en door de bewoners die dit ook relatief meer vinden dan toeristen. Die bewoners vinden ook vaker dat het Nationaal Park Weerribben-Wieden de favoriete plek is om te recreëren/ontspannen en ze kennen ook vaker allerlei verhalen over dit park dan toeristen en dagbezoekers. De persoonlijke verhalen als vorm van verbondenheid wordt relatief vaker genoemd door alleen de bezoekers die er vaker komen.

De verbondenheid met het Nationaal Park Weerribben-Wieden is dus redelijk hoog en dan vooral bij bezoekers die er vaker komen en bij de bewoners. Dit komt onder andere ook tot uiting in de redenen die de respondenten spontaan noemen om het gebied te bezoeken. Daar zitten vaak verwijzingen naar vroeger bij, toen ze er nog woonden of er vaak kwamen bij grootouders of vrienden. Deze verbondenheid kan vervolgens weer leiden tot een soort promotie van het gebied. Dat kan weer van invloed zijn op toeristen die op basis van die verhalen besluiten een vakantie te vieren in de Weerribben-Wieden of er een dagtochtje van te maken.

De bezoekers die er vaker komen zijn in verhouding ook meer betrokken bij het park. Ongeveer een kwart (24\%) van de bezoekers is (zeer) betrokken bij het park. De meeste (42\%) bezoekers zijn neutraal en $34 \%$ is niet (zeer) betrokken. De bezoekers die er vaker komen en de bewoners volgen de ontwikkelingen over dit park relatief meer. Ook nu is iets meer dan een kwart ( $27 \%$ ) het (zeer) eens met deze stelling en $38 \%$ het (zeer) oneens.

De betrokkenheid met het Nationaal Park Weerribben-Wieden is beperkter dan de verbondenheid. De betrokkenheid is groter bij bezoekers die er vaker komen.

Deze verbondenheid en betrokkenheid van de bezoekers heeft sterke positieve relaties met het trots zijn op het gebied. Van de bezoekers zegt $61 \%$ trots te zijn op het Nationaal Park Weerribben-Wieden en in verhouding zijn dat relatief vaker bezoekers die er vaker komen en bewoners. Circa $8 \%$ is niet (zeer) trots.

Ten slotte zegt $68 \%$ het (zeer) mee eens te zijn dat de Weerribben-Wieden een typisch Nederlands Nationaal Park is. Ongeveer $6 \%$ is het hiermee (zeer) oneens. Bewoners zeggen relatief vaker dan toeristen dat dit een typisch Nederlands Nationaal Park is.

Samenvattend kan gesteld worden dat de toegevoegde sociaal-emotionele waarde van het label Nationaal Park voor de Weerribben-Wieden hoog is. Dit geldt relatief meer voor bezoekers die er vaker 
komen en voor de bewoners. De affiniteit met het gebied werkt vooral via de verbondenheid en iets minder via de betrokkenheid.

\subsection{De economische effecten van het label Nationaal Park}

De economische toegevoegde waarde van het label is al in Hoofdstuk 3 aan de orde geweest met een gemiddelde besteding van $€ 19$,- per persoon per dag. Interessant is om te onderzoeken wat het economisch effect is als het natuurgebied geen label zou dragen. Uit het voorgaande weten we dat:

1. Een aantal bezoekers dan niet zou komen.

2. Voor een aantal bezoekers het een doorslaggevende rol voor bezoek is dat het natuurgebied een Nationaal Park is.

3. Respondenten die zeggen dat het zeer uitmaakt of een natuurgebied een Nationaal Park is.

4. Respondenten die het zeer jammer vinden als Nederland geen Nationale Parken meer zou kennen.

De antwoorden correleren ook significant met elkaar. Het is dus een bepaalde groep bezoekers. Om deze groep nader te onderzoeken is het wel van belang om alleen die respondenten te selecteren die weten dat het natuurgebied Weerribben-Wieden een Nationaal Park is. Het blijkt dan dat circa 34\% van de Nederlanders label-gevoelig is. Deze label-gevoelige Nederlanders zijn goed voor $40 \%$ van de totale bestedingen. Daarmee kan gesteld worden dat de economische waarde van het label $40 \%$ is (Tabel 10). Als de Weerribben-Wieden het label Nationaal Park niet meer zou gebruiken en de aanname is dat deze label-gevoelige Nederlanders dan niet meer zouden komen, dan zou het bedrijfsleven rond het natuurgebied Weerribben-Wieden een omzetdaling kunnen hebben van gemiddeld $€ 19,20$ naar $€ 17,50$ ofwel $9 \%$.

Tabel 10 Invloed van het label op aantal bezoekers en bestedingen (incl. geen bestedingen)

\begin{tabular}{lrrrrr} 
Item & Total & \multicolumn{2}{c}{$\begin{array}{c}\text { Label } \\
\text { Gevoelig }\end{array}$} & \multicolumn{2}{c}{$\begin{array}{c}\text { Label } \\
\text { Ongevoelig }\end{array}$} \\
& $\mathrm{N}$ & $\mathrm{N}$ & $\%$ & $\mathrm{~N}$ & $\%$ \\
\hline Totaal bezoekers & 4800 & 1646 & 34 & 3154 & 66 \\
\hline Totaal bestedingen & 92.171 & 36.971 & 40 & 55.200 & 60 \\
\hline Bestedingen per bezoeker & 19,20 & 22,50 & & 17,50 & \\
\hline
\end{tabular}

Het is de vraag of het laatste antwoord (4) wel direct aan de Weerribben-Wieden mag worden toegerekend. Het is niet erg waarschijnlijk dat er in Nederland geen Nationale Parken meer zouden zijn. Dan is $11 \%$ van de totale bestedingen afkomstig van deze groep respondenten. Wanneer alleen de respondenten worden geselecteerd van antwoorden 1 en 2, dan blijkt dat de bestedingen van deze groep $9 \%$ is van het totaal. Als de Weerribben-Wieden het label Nationaal Park niet meer gebruikt en de aanname is dat deze groep Nederlanders dan niet meer zou komen, dan zou het bedrijfsleven rond het natuurgebied Weerribben-Wieden een omzetdaling kunnen hebben van bijna $2 \%$.

Geconcludeerd kan worden dat de economische toegevoegde waarde van het label voor de Weerribben-Wieden geschat kan worden tussen de $10 \%$ en $40 \%$. Zonder het label is de WeerribbenWieden een 'gewoon' natuurgebied en moeten de beheerder en het bedrijfsleven zelf de naam Weerribben-Wieden als merk promoten. Dat is mogelijk, want de Weerribben-Wieden heeft al een bepaalde mate van bekendheid opgebouwd en er zijn meer natuurgebieden waarbij de naam een sterk merk is zoals 'het Vondelpark' of 'de Oostvaardersplassen'. Het label 'Nationaal Park' is echter al een sterk en internationaal merk. Voor de Weerribben-Wieden is het dan eenvoudiger om op dit label mee te liften. 


\section{Conclusies en aanbevelingen}

\section{$5.1 \quad$ Inleiding}

In dit hoofdstuk wordt een antwoord gegeven op de onderzoeksvragen en worden de belangrijkste conclusies en aanbevelingen weergegeven. De literatuur geeft geen eenduidig beeld van het effect van het dragen van het label Nationaal Park op het bezoek, maar wel dat het label gepaard gaat met diverse waarden zoals de gebruikswaarde en de sociaal-emotionele waarde.

\subsection{Conclusies}

Wellicht de belangrijkste conclusie is dat $83 \%$ van de bezoekers zegt te weten dat de WeerribbenWieden een Nationaal Park is. Bewoners zijn in verhouding hiervan meer op de hoogte dan toeristen die dit weer relatief meer weten dan dagbezoekers.

\section{Wat is de invloed van het label Nationaal Park op de beslissing van toeristen om de Weerribben-Wieden te bezoeken?}

Het antwoord op de vraag wat de invloed van het label Nationaal Park is op de beslissing van toeristen om de Weerribben-Wieden te bezoeken, ligt genuanceerd. Van de Nederlanders zegt 34\% gevoelig voor het label 'Nationaal Park' te zijn. Een directe invloed op het bezoek aan de Weerribben-Wieden is beperkt. Slecht $2 \%$ van de respondenten die weten dat de Weerribben-Wieden een Nationaal Park is, zou het natuurgebied niet bezoeken als het geen Nationaal Park zou zijn. Daarentegen zegt $25 \%$ dat het label Nationaal Park een (doorslaggevende) rol heeft gespeeld bij de beslissing om het natuurgebied te bezoeken. Het label Nationaal Park heeft dus wel enig invloed. Met name bij bezoekers die het gebied vaker bezoeken. Het lijkt er dus op de het label 'Nationaal Park' herhalingsbezoek stimuleert.

Maar belangrijkere redenen bij de beslissing om het gebied te bezoeken zijn rust en ontspanning en om gezellig tijd door te brengen met gezin / vrienden / familie. Maar ook om iets te leren over de natuur is een belangrijke reden evenals om Giethoorn te zien en dan gelijk het Nationaal Park mee te nemen in het bezoek.

De meerderheid van de Nederlanders vindt niet dat het label 'Nationaal Park' voor de WeerribbenWieden afgeschaft mag worden maar dat er juist extra geïnvesteerd moet worden in natuur en toerisme.

Wat is de toegevoegde waarde van het label Nationaal Park voor de Weerribben-Wieden? De conclusie is dat de toegevoegde waarde van het label wordt gevormd door de gebruikswaarde (bezoek en economische waarden) en de sociaal-emotionele waarden (niet-gebruikswaarde en affiniteit). Het label Nationaal Park geeft een gebied een specifieke status en schept verwachtingen over de kwaliteit en uniciteit. Zonder label zal de Weerribben-Wieden een natuurgebied zijn zoals alle andere natuurgebieden en dus niet speciaal. Daardoor is er voor een deel van de toeristen geen of minder reden meer om het te bezoeken (met name voor de label-gevoelige toeristen).

\section{Gebruikswaarde}

\section{- Bezoek}

Het merendeel van de bezoekers kan als dagbezoeker worden bestempeld, gevolgd door toeristen en ten slotte bewoners. De dagbezoeker komt vooral uit Overijssel en de noordelijke drie provincies. De provincies Zuid- en Noord-Holland en Noord-Brabant zijn de grootste leveranciers van toeristen. Van de bewoners komt het merendeel uit de gemeente Steenwijkerland, gevolgd door Meppel en de Noordoostpolder. Circa een derde van alle bezoekers woont binnen een straal van $50 \mathrm{~km}$ van het Nationaal Park Weerribben-Wieden. De toeristen verblijven het meest in Giethoorn. De meeste toeristen verblijven op de camping. Een ruime meerderheid van alle bezoekers bezoekt Nationaal Park 
Weerribben-Wieden één of enkele keren per jaar. In verhouding bezoeken de bewoners en toeristen het park vaker dan de dagbezoekers. Gemiddeld blijft men ongeveer 3 uur in het Nationaal Park. De gemiddelde groepsgrootte is 4,3 personen. Gemiddeld worden er 3,2 recreatieactiviteiten ondernomen door de bezoekers. Met gemiddeld 3,9 activiteiten ondernemen bewoners significant meer activiteiten dan dagbezoekers die gemiddeld 3,1 activiteiten ondernemen. Toeristen ondernemen in verhouding de minste activiteiten, namelijk 3,0. Wandelen en fietsen zijn de meest populaire activiteiten, gevolgd door een bezoek aan een café/restaurant of een info/bezoekerscentrum. Bezoekers die vaker komen, ondernemen vaker sportieve activiteiten.

Het gemiddelde rapportcijfer voor de waardering van het Nationaal Park Weerribben-Wieden is een 8,2. De bewoners waarderen het gebied hoger dan toeristen en dagbezoekers.

Een meerderheid van de bezoekers is het er (zeer) mee eens dat de Weerribben-Wieden een heel mooi gebied is, geschikt is om een middagje te ontspannen en belangrijk is voor het beschermen van de natuur. Deze gebiedskwaliteiten zijn essentieel en de instandhouding hiervan is zeer belangrijk voor de sector recreatie en toerisme.

\section{- Economische waarden}

lets meer dan drie kwart van de bezoekers zegt geld te hebben uitgegeven tijdens hun bezoek aan het Nationaal Park de Weerribben-Wieden. Opvallend is dat bewoners in verhouding significant meer aangeven geen geld te hebben uitgegeven.

Gemiddeld besteedt een persoon $€ 19,20$ per dag in of rond het Nationaal Park Weerribben-Wieden. De economische waarde van het natuurgebied wordt meer bepaald door toeristen dan door bewoners en dagbezoekers. Toeristen geven gemiddeld twee keer zoveel uit dan bewoners en dagbezoekers. Het meest wordt besteed in restaurants en cafés. Toeristen geven twee keer zoveel meer uit in de horeca dan bewoners en dagbezoekers.

Zonder het label Nationaal Park zouden de label-gevoelige Nederlanders wellicht niet meer komen en kan het bedrijfsleven rond het natuurgebied Weerribben-Wieden een omzetdaling krijgen tussen de 2 en $9 \%$. De economische toegevoegde waarde van het label kan geschat worden tussen de $10 \%$ en $40 \%$ waarbij het eerder bij de $10 \%$ zit als bij de $40 \%$, omdat er een verschil is tussen wat mensen zeggen dat ze doen en daadwerkelijk doen.

\section{Sociaal-emotionele waarden}

- Niet-gebruikswaarde Het draagvlak voor het behoud en bescherming van natuurgebied Weerribben-Wieden kan worden vergroot als er kennis is welke sociaal-emotionele waarden mensen hebben met het natuurgebied Weerribben-Wieden. De conclusie is dat de niet-gebruikswaarde als onderdeel van deze sociaalemotionele waarden hoog is voor het Nationaal Park Weerribben-Wieden. Het gaat vooral om de optiewaarde, de altruïstische waarde, de bestaanswaarde en iets minder de verervingswaarde. Dit geldt vooral voor de bewoners.

\section{- affiniteit}

De affiniteit met de Weerribben-Wieden is redelijk hoog te noemen. Dit komt vooral door het gevoel van verbondenheid en trots (en dan vooral bij bezoekers die er vaker komen en bij de bewoners), en minder door de betrokkenheid met het gebied. De betrokkenheid is groter bij bezoekers die er vaker komen. Een meerderheid zegt dat de Weerribben-Wieden een typisch Nederlands Nationaal Park is. Bewoners zeggen dit relatief vaker dan toeristen.

\section{Label Nationaal Park in het algemeen}

Nederlanders zijn gehecht aan de Nederlandse Nationale Parken want $81 \%$ zegt dat het (zeer) jammer zou zijn als Nederland geen Nationale Parken meer zou kennen. Voor 22\% maakt het echt een verschil of een natuurgebied een Nationaal Park is. Een Nationaal Park is volgens de Nederlanders dan ook een door de overheid beschermd natuurgebied met ongerepte natuur dat iets unieks heeft met goede recreatief-toeristische voorzieningen. 
Uit dit onderzoek blijkt dat toeristen vooral de economische waarden van het label Nationaal Park voor de Weerribben-Wieden bepalen en de bewoners vooral de sociaal-emotionele waarden van het label. Dit komt redelijk overeen met de (inter) nationale literatuur. De conclusie uit de literatuur dat Nationale Parken een significante bijdrage leveren aan de economie van lokale regio's en aangrenzende dorpen en/of steden door middel van toeristische uitgaven, kan onderschreven worden. De sociaal-emotionele waarden zijn belangrijk voor het vergroten van het ecologisch en economisch belang van een Nationaal Park. Het draagvlak voor het behoud en bescherming van natuurgebieden kan ermee worden vergroot. De affiniteit van mensen die daarvoor nodig is, is in en rond de Weerribben-Wieden aanwezig.

\subsection{Aanbevelingen}

Gezien de conclusies wordt aanbevolen dat het waardevol is om het label Nationaal Park voor de Weerribben-Wieden te behouden. Een heldere merkpositionering van het label Nationaal Park Weerribben-Wieden onderscheidt het gebied zich van andere natuurgebieden waarbij de nadruk kan worden gelegd op de volgende merkwaarden in relatie tot de activiteiten die worden ondernomen: bijzonder, verrassend, divers (natuur en activiteiten) en toegankelijk (voor ieder wat wils). Daarbij zal een verschil in promotie en promotiemiddelen gerelateerd moeten zijn aan de verwachtingen van de type bezoeker (bewoner, dagbezoeker, toerist). Dit is in lijn met Richards (2002) die concludeert dat er een sterk verband is tussen motivatie, werkelijk bezoek en het gebruik van markers. Het recreatieftoeristisch bedrijfsleven zal zich vooral en nog meer moeten richten op de dagbezoeker en de toerist. Dit kan in de vorm van aantrekkelijke arrangementen, het organiseren van diverse evenementen/lezingen en excursies. Met name de aantrekkingskracht van Giethoorn kan gebruikt worden om toeristen te verleiden het Nationaal Park te bezoeken. Dit kan door afspraken te maken met touroperators, horeca-ondernemers in Giethoorn via bijvoorbeeld een 'horeca-hopping' in de Weerribben-Wieden. Wellicht is zelfs te overwegen om een derde bezoekerscentrum te ontwikkelen in Giethoorn.

Het succes van de toegevoegde waarde van het label is ook te vergroten wanneer de beheerders zo goed mogelijk inspelen op de affiniteit van de bezoekers met het Nationaal Park. Dit zijn dan met name bewoners en bezoekers die er vaker komen. Het verspreiden van de nieuwsbrief onder de 'vrienden van' dat reeds wordt gedaan, is een goede manier om de affiniteit te behouden en mogelijk te vergroten. De ontvangers van de nieuwsbrief zijn een soort ambassadeurs van het natuurgebied en via de nieuwsbrief zijn er mogelijkheden om acties en evenementen te organiseren om de band met deze bezoekers te versterken. Een mogelijkheid is om bijvoorbeeld kortingsacties te indien ze andere toeristen overhalen om ook een bezoek te brengen aan de Weerribben-Wieden of ook een abonnement te nemen op de nieuwsbrief. Deze ambassadeurs zijn bij uitstek geschikt om het mentale beeld van andere toekomstige bezoekers verder in te kleuren.

De opvatting van Nederlanders dat het natuurgebied als Nationaal Park een beschermde status heeft kan gevolgen hebben bij een gebiedsuitbreiding van het gebied. Een eventuele uitbreiding van het Nationaal Park Weerribben-Wieden zou dan bij voorkeur moeten gebeuren met gebieden die al een wettelijke status van bescherming bieden die Nederlanders verwachten van een Nationaal Park. Indien de uitbreiding gepaard gaat met gebieden die niet de wettelijke status van bescherming bieden en er worden activiteiten ondernomen die ten koste van de natuur zouden kunnen gaan (zoals bebouwing), dan zal dit wellicht weerstand opwekken bij de bezoekers. Dit kan komen omdat ze denken dat het gebied beschermd is en dat die activiteit niet thuis hoort in een beschermd natuurgebied. In de communicatie is het dan raadzaam te benadrukken dat het label Nationaal Park zelf het natuurgebied geen beschermde status geeft.

Een Nationaal Park roept verwachtingen op bij het publiek dat het weliswaar een beschermd gebied is, maar ook een uniek gebied met goede recreatief-toeristische voorzieningen. Dit brengt bepaalde verplichtingen met zich mee in het beheer en onderhoud van het natuurgebied. Het label werkt als een marker waarmee het zich duidelijk onderscheid van andere natuurgebieden. Zoals Leiper (1990) stelt heeft de marker invloed op de perceptie van de toerist op het gebied en roept het bepaalde connotaties op. Dit kan tot gevolg hebben dat een toerist het specifieke gebied wil gaan bezoeken. Het 
label Nationaal Park is een sterk internationaal merk en de Weerribben-Wieden kan op deze bekendheid meeliften. Het is in ieders belang dat de huidige hoge waardering van de WeerribbenWieden gehandhaafd blijft door goede onderlinge afspraken te maken met de diverse stakeholders over een verdeling van de kosten van het beheer, onderhoud en promotie van het natuurgebied en de recreatief-toeristische voorzieningen.

De stakeholders van het Nationaal Park de Weerribben-Wieden hebben als doel de toegevoegde waarde van het label Nationaal Park te vergroten. Om dit te bereiken wijzen wij op de aanbevelingen van de Stichting Wetenschappelijk Onderzoek Commerciële Communicatie. Zij hebben 10 algemene ijkpunten van een sterk label opgesteld. Deze ijkpunten geven alle partijen inzicht in wat nodig is om een sterk label te ontwikkelen en bieden een afwegingskader met betrekking tot de inzet van mensen en middelen in bestaande en nieuwe marketingconcepten. Deze 10 ijkpunten van een sterk label zijn:

1. Beschikt over een onderscheidend concept.

2. Heeft een goede relatie met zijn omgeving.

3. Heeft een doel en een visie.

4. Is verankerd in het doen en laten van medewerkers.

5. Communiceert consequent en uniek.

6. Heeft online volgers.

7. Werkt samen met klanten.

8. Vitaliseert en innoveert.

9. Heeft een sterke positie in distributiekanalen.

10. Heeft investeerders.

Gezien het feit dat 34\% van de Nederlanders label-gevoelig is, is het raadzaam om in alle promotieen communicatie uitingen over de Weerribben-Wieden het label 'Nationaal Park' zichtbaar te voeren. Het effect van deze actie kan dan over twee a drie jaar onderzocht worden door dezelfde vragenlijst nogmaals af te nemen en te vergelijken met de resultaten van deze vragenlijst. De kosten van een dergelijk onderzoek worden geschat op $€ 15.000$,-

Om de economische impact van het Nationaal Park te vergoten is het op basis van de resultaten van dit onderzoek raadzaam om zich meer te richten op toeristen. Deze besteden meer in de horeca en besteden in het ook algemeen meer, zelfs indien de overnachtingskosten worden afgetrokken. Er lijkt nog groei te zitten in de bestedingen in de horeca, want driekwart van de bezoekers geeft aan geen bezoek te hebben gebracht aan de horeca. Wellicht komt dit omdat er te weinig horeca is. Of dat de ligging van de huidige horeca niet helemaal overeenkomt met de spreiding van de bezoekers over het gebied. Het verdient ook aanbeveling om gerichte acties te gaan ondernemen om bezoekers over te halen een bezoek te brengen aan de horeca.

Bewoners geven minder uit maar het is wel interessant om de absolute omvang van de bewoners, dagbezoekers en toeristen te onderzoeken. Daarmee kan de totale omzet worden bepaald en worden achterhaald hoe de verdeling tussen de bewoners, dagbezoekers en toeristen precies is. Daarvoor kan een monitoringsonderzoek worden opgesteld dat (eventueel jaarlijks en per dag) de omvang en de spreiding van het bezoek in de Weerribben-Wieden in kaart brengt in combinatie met een steekproef onder bezoekers naar die verdeling. Daarmee kan er invulling worden gegeven aan de sleutelelementen ASBTW (Goossen, 2016) die van belang zijn voor een goed functioneren van een Nationaal Park. De A staat voor Aantal bezoeken per jaar; de S voor Spreiding van bezoekers over het gebied; de B voor Bestedingen; de T voor Tevredenheid en de W voor Wensen van de bezoeker.

Gegevens over de B en T zijn in dit rapport al opgenomen. Het verzamelen van data over de A, S en $W$ is dan nog nodig. Er zijn voornemens bij de beheerder van het Nationaal Park Weerribben-Wieden om in 2017 de A en de W te laten onderzoeken. De Spreiding van de bezoekers over het gebied staat dan nog open. Inzicht in de spreiding is vooral voor de beheerder en de horeca belangrijk. Met nieuwe sensortechnieken is deze spreiding te achterhalen tegen geringe kosten. Globaal moet gedacht worden aan een eenmalig investering van $€ 7.500$,- en een jaarlijkse data-analyse van $€ 2.000,-$. Voordeel van deze sensortechniek is dat ook gelijk de A wordt onderzocht.

Nader onderzoek is ook nodig om het totaal aan indirecte bestedingen uit te zoeken om op deze wijze de economische impact van Nationaal Park Weerribben-Wieden op de regio te kunnen bepalen. 
Uit de literatuur blijkt dat het label Nationaal Park anders werkt voor binnenlandse en buitenlandse toeristen. Buitenlandse toeristen komen eerder door de status van Nationaal Park dan lokale toeristen die andere motieven hebben om een gebied te bezoeken. Voor een vervolgonderzoek is het dus van belang om deze verdeling tussen binnenlandse en buitenlandse toeristen te maken en te analyseren. Een mogelijkheid hiervoor is om dit onderzoek te herhalen voor de buitenlandse toerist. Dit kan bijvoorbeeld via een online-vragenlijst door gebruik te maken van de email-adressen die het bedrijfsleven heeft van haar buitenlandse klanten. 


\section{Literatuur}

AMG, 2016. Adviesrapport 'Invloed van het label Nationaal Park - Bezoek aan de Drentsche Aa'. Adviesbureau Maatschappelijk Groen (AMG) bestaat uit Jennifer Jansen, Lianne de Jong, Ellen van der Linde, Christiaan Krause, Iris van der Wiel en Meia van der Zee. Studenten aan Wageningen Universiteit.

Arnberger, A., Eder, R., Allex, B., Sterl, P., \& Burns, R. C. (2012). Relationships between national-park affinity and attitudes towards protected area management of visitors to the Gesaeuse National Park, Austria. Forest Policy and Economics, 19, 48-55.

Bade, T., R. Enzerink en G. Smid. 2008. Kop en munt, Nationaal Park Weerribben-Wieden als Drager van de regionale Economie. Arnhem, Triple E Productions.

Beerli, A., \& Martin, J. D. (2004). Factors influencing destination image. Annals of tourism research, 31(3), 657-681.

Borrie, W. T., Freimund, W. A., \& Davenport, M. A. (2002). Winter visitors to Yellowstone National Park, their value orientations and support for management actions. Human ecology review, 9, 41.

Buckley, R., 2002. World Heritage Icon Value: Contribution of World Heritage Branding to Nature Tourism. International Centre for Ecotourism Research Faculty of Environmental Sciences. Griffith University Queensland.

Capel, J., H. Hulsman, P. van der Kraan, C. Lorika, A. Ponari \& L. van der Putten, 2007. Economic Valuation of National Park Zuid-Kennemerland. A pilot study of different valuation approaches. VU University, Master Environment and Resource Management. Amsterdam.

Carlsen, J., \& Wood, D. S. (2004). Assessment of the economic value of recreation and tourism in Western Australia's national parks, marine parks and forests. Gold Coast, Queensland: CRC for Sustainable Tourism.

Cumulus Consultants \& ICF GHK, 2013. Valuing England's National Parks.

Daams, M. N. 2016. Rethinking the economic valuation of natural land: Spatial analyses of how deeply people value nature in rural areas and in cities. Rijksuniversiteit Groningen. 243 p.

Eagles, P. (2001, September). International trends in park tourism. In EUROPARC 2001 Conference, October (pp. 3-7).

Elands, B. H. M., van Marwijk, R. B. M., Jochem, R., Pouwels, R., \& de Boer, T. A. (2005). Natuur in Nederland: recreatie en biodiversiteit in balans (No. 1220, p. 96). Alterra.

Folmer, A., 2016. Wildlife: a hidden treasure of green places in urbanized societies? : A study into whether and how wildlife contributes to a bond with green places among lay people in the Netherlands. [Groningen] : University of Groningen, 2016. 196 p.

Fredman, P., L. Ho“ rnsten Friberg, and L. Emmelin 2005 Friluftsliv och turism i Fulufja“ Ilet. Fo" reefter nationalparksbildningen. (Outdoor Recreation and Tourism in Fulufja" llet: Before and After the National Park Designation). Naturva ${ }^{\circ}$ rdsverket, rapport 5467. Dokumentation av de svenska nationalparkerna, nr 18. 2007 Increased Visitation from National Park Designation. Current Issues in Tourism 10:87-95.

Goossen, C.M. \& T.A. de Boer, 2006. Houding en wensen van bewoners ten aanzien van het begrip Nationaal Landschap. Wageningen, Alterra. Alterra-rapport 1306.

Goossen, C.M., J. Vreke \& T.A. de Boer, 2007. De recreatieve en economische betekenis van het Zuiderpark in Den Haag en het Nationaal Park De Hoge Veluwe. Wageningen.

Goossen, C.M., 2016. Lezing op het symposium Monitoring Nationale parken op 16 juni 2016 te Mariënhof, Amersfoort. http://docplayer.nl/20506178-Key-performance-indicators-toolprofijtmeting-nationale-parken.html

Govers, R., Go, F. M., \& Kumar, K. (2007). Promoting tourism destination image. Journal of Travel Research, 46(1), 15-23.

Hall, M., and R. Piggin 2001 Tourism Business Knowledge of World Heritage Sites: a New Zealand Case Study. International Journal of Tourism Research 4:401-411.

Keefer, W. R. (1971). The geologic story of Yellowstone national park (No. 1347). US Geological Survey. 
Klijs, J. \& D. Korteweg Maris, 2014. Economische effectrapportage Vrijetijdseconomie Zeeland 2013; Technische rapportage. Kenniscentrum Kusttoerisme. HZ University of Applied Sciences, Vlissingen.

Konecnik, M., \& Go, F. (2008). Tourism destination brand identity: The case of Slovenia. Journal of Brand Management, 15(3), 177-189.

Leiper, N. 1990 Tourist Attraction Systems. Annals of Tourism Research 17:367-384.

Lew, A. 1987 A Framework of Tourist Attraction Research. Annals of Tourism Research14:553-575.

MacCannell, D. 1976 The Tourist: A New Theory of the Leisure Class. New York: Schocken Books. 1992 Empty Meeting Grounds. London: Routledge.

MarketingOost, 2016. Bezoekers aan Steenwijkerland. Op basis van Vodafone-data / View. dat. MarketingOost Kennis, Innovatie \& Productontwikkeling. Zwolle, april 2016

Motivaction, 2016. Rapportage Imago- en positioneringsonderzoek. Programma Nationale Parken van Wereldklasse

Nolte, B. 2004 Sustainable Tourism in Biosphere Reserves of East Central European Countries: Case Studies from Slovakia, Hungary and the Czech Republic. In Policies, Methods and Tools for Visitor Management, T. Sievanen, J. Erkkonen, J. Jokima“ ki, J. Saarinen, S. Tuuletie and E. Virtanen, eds., pp. 349-356. Rovaniemi: Proceedings of the Second International Conference on Monitoring and Management of Visitor Flows in Recreational and Protected Areas.

NPWW, 2010. Strategisch Meerjarenplan Communicatie Nationaal Park Weerribben-Wieden 20102015.

NPWW, 2015. Startdocument Nationaal Park Weerribben-Wieden nieuwe stijl.

Perman, Roger, et al., 2003, Natural Resource and Environment Economics, Pearson, 3rd edition, pp. 401-403.

Progressive (2015) Cairngorns National Park Visitor Survey 2014/15. Presentation of Findings. Full report. Online beschikbaar via: http://cairngorms.co.uk/wpcontent/uploads/2015/10/150831CairngormsVisitorSurveyPresentationv1.01.pdf

Reinius, S. W., \& Fredman, P. (2007). Protected areas as attractions. Annals of Tourism Research, 34(4), 839-854.

Richards, G. 2002 Tourism Attraction Systems: Exploring Cultural Behavior. Annals of Tourism Research 29: 1048-1064.

Schägner Jan Philipp, Luke Brander, J oachim Maes, Maria Luisa Paracchini \& Volkmar Hartje, 2016. Mapping recreational visits and values of European National Parks by combining statistical modelling and unit value transfer. Journal for Nature Conservation 31, 2016, 71-84.

Shamai, S. (1991). Sense of place: An empirical measurement. Geoforum,22(3), 347-358.

SNP (2016). Nationaalpark.nl. Laatst bekeken 23/05/2016, van http://www. nationaalpark.nl/documents/home. $x m$ l?lang=nl

SQW (2006). Prosperity and Protection - The economic impact of National Parks in the Yorkshire and Humber regions. Report for the Council for National Parks

Triple E, 2010. De groene toegevoegde waarde. Over de economische kansen van de Drentsche Aa.

Walsh, R.G., J.B. Loomis and R.A. Gillan, 1984. 'Valuing Option, Existence and Bequest Demands for Wilderness,' Land Economics, 60: 14-29

Weiler, S., and A. Seidl 2004 What's in a Name? Extracting Econometric Drivers to Assess the Impact of National Park Designation. J ournal of Regional Science 44:245-262. 


\section{Bijlage 1 Recreatieactiviteiten}

In onderstaande Tabel staan de percentages aan recreatieactiviteiten die in het Nationaal Park Weerribben-Wieden worden ondernomen, verdeeld per type bezoeker. Een sterretje $\left(^{*}\right)$ geeft aan dat er een significant verschil is tussen de type bezoeker voor die activiteit.

\begin{tabular}{|c|c|c|c|c|}
\hline Activiteit & $\%$ Bewoner & \% Dagbezoeker & $\%$ Toerist & N \\
\hline Wandelen* & 17 & 57 & 26 & 626 \\
\hline Fietsen op eigen fiets* & 20 & 47 & 32 & 411 \\
\hline Bezoek aan restaurant/café* & 18 & 59 & 23 & 306 \\
\hline Bezoek aan infocentrum/bezoekerscentrum & 16 & 52 & 32 & 292 \\
\hline Zitten/lezen/luieren & 15 & 57 & 28 & 195 \\
\hline Zeilen/motorbootvaren in een gehuurde boot & 11 & 65 & 24 & 174 \\
\hline Meedoen met een vaarexcursie & 8 & 59 & 33 & 172 \\
\hline Kanoën/roeien in een gehuurde boot & 16 & 62 & 22 & 170 \\
\hline Picknicken* & 12 & 69 & 19 & 157 \\
\hline Natuurstudie/fotograferen/vogels observeren & 13 & 59 & 28 & 128 \\
\hline Schaatsen & 29 & 60 & 10 & 116 \\
\hline Zeilen/motorbootvaren met eigen boot & 21 & 49 & 29 & 96 \\
\hline Zwemmen* & 20 & 65 & 15 & 94 \\
\hline Vissen & 14 & 64 & 22 & 78 \\
\hline Hond uitlaten & 18 & 57 & 25 & 72 \\
\hline Fietsen op gehuurde fiets* & 1 & 67 & 31 & 70 \\
\hline Evenement bezocht* & 25 & 61 & 14 & 59 \\
\hline Meedoen aan wandelexcursie & 7 & 67 & 26 & 58 \\
\hline Kanoën/roeien met eigen boot & 19 & 56 & 26 & 43 \\
\hline Trimmen/joggen/hardlopen & 10 & 68 & 22 & 41 \\
\hline Wielrennen (individueel) & 14 & 72 & 14 & 36 \\
\hline Mountainbiken (individueel)* & 15 & 81 & 4 & 26 \\
\hline Wielrennen (in groepsverband) & 13 & 79 & 8 & 24 \\
\hline Surfen op eigen surfplank & 5 & 68 & 26 & 19 \\
\hline Meedoen aan tocht per paard en wagen & 0 & 76 & 24 & 17 \\
\hline Meedoen met een fietsexcursie & 7 & 67 & 27 & 15 \\
\hline Surfen op gehuurde surfplank & 9 & 91 & 0 & 11 \\
\hline Mountainbiken (in groepsverband) & 22 & 78 & 0 & 9 \\
\hline Auto/motor rijden & 33 & 67 & 0 & 9 \\
\hline Paardrijden op eigen paard & 14 & 29 & 57 & 7 \\
\hline Paardrijden op gehuurde paard & 0 & 57 & 43 & 7 \\
\hline Skaten/skeeleren & 29 & 71 & 0 & 7 \\
\hline
\end{tabular}




\section{Bijlage 2 Bestedingen}

Gemiddelde uitgaven $(€)$ per persoon per dag, exclusief diegene die geen geld hebben uitgegeven

\begin{tabular}{lr} 
Type uitgave & Gemiddeld \\
\hline Restaurants en cafés & 14,38 \\
\hline Winkels incl. supermarkt & 10,60 \\
\hline Overnachting (omgerekend naar prijs per nacht)* & 26,24 \\
\hline Huur van goederen (zoals fiets, fluisterboot, kano etc.) & 12,52 \\
\hline Excursie (vaar, fiets, wandel etc.) & 9,24 \\
\hline Souvenirs & 6,57 \\
\hline Onderhoud en reparatie & 10,29 \\
\hline Brochures /folders/ kaarten & 3,63 \\
\hline Parkeergeld in Weerribben-Wieden/Giethoorn & 3,49 \\
\hline Vervoerskosten & 10,50 \\
\hline Overige uitgaven in Weerribben-Wieden en de omgeving & 10,10 \\
\hline Totaal & 35,40 \\
\hline
\end{tabular}




\section{Bijlage 3 Redenen voor bezoek}

(Voormalige) Zuiderzeeroute voor fietsers, tegenwoordig aaneengesloten LF-routes.

mooi gebied gewoon

Accommodatie met culinair aanbod voor 2 daags verblijf, dan ook natuurgebieden opzoeken

alle tijden van het jaar mooi

alleen jammer dat de fietspaden zo erg smal zijn

Alles is altijd netjes en de paden zijn duidelijk. daarbij zijn er genoeg plekken om even een drankje te doen en te genieten van de omgeving.

Als de kanovereniging een kampeerweekend organiseert naar dit park ga ik mee. het is een mooi kanogebied. Ik zal niet zo snel specifiek dit gebied uitzoeken voor een eigen (geen-kano)-vakantie. Er zijn genoeg mooie natuurgebieden in Nederland waar we heen kunnen.

Als er natuur ijs is

bekenden, vrienden ontmoeten

Belangrijkste reden dat het een uniek prachtig natuurgebied is . belangrijkste reden is gezellig met de familie er op uit

Ben in de omgeving geboren

ben lid van KBO Meijel en we zijn daar met een bus naar toe gegaan. Prachtig park en geweldige uitleg over het ontstaan, hetzelfde geldt voor De Groote Peel.

Bestaande relatie met de vrij willigers van Natuurmonumenten

Bezoek te brengen aan Blokzijl en aan Geertien

Bij een weekend weg in de buurt

bijzonder gebied

bijzondere vogels

Buitengewoon aantrekkelijk gebied met leuke dorpjes/stadjes zoals bijvoorbeeld Giethoorn en

Zwartsluis

De gehele sfeer en de gezelligheid.

de reis ernaar toe is ook mooi.

De rust, ruimte en de natuur

De rust en ontspanning

De rust en stilte in de herfst en winter

de rust, de ruimte, frisse lucht

De schoonheid van de natuur

De spectaculair mooie natuur die zich enorm leent voor hele mooie foto's

Dichtbij en zeer veel natuur. Heerlijk om ontspannend te wandelen en genieten van alle jaargetijden. dochter woont in de omgeving

door het mooie uitzicht

dagje aan en op het water

Een ander mooi stukje Nederland bekijken

Een bezoekje met familie uit het buitenland

een dag uit

een feestje geven of lekker uit eten gaan

Een heerlijk gebied om te wandelen en te fietsen

een prettige camping om te overnachten in Paasloo

Eigenlijk de hoofdreden: Voor mijn werk fietst ik in de zomermaanden tussen huis en locatie werk door een deel van de Weerribben.

$\mathrm{Er}$ is in de buurt accommodatie van familie waardoor een keer daarheen makkelijk en goedkoop is

Er lopen prachtige wandelpaden door.

Er zijn leuke wandelroutes

Erg mooi gebied, veel te doen

Erg mooi gebied om met de kano en de familie rond te gaan

Even lekker weg zijn

Even ontspannen. 
excursie, onderwijs verzorgen

Familie bezoek

fietsvakantie...

Fijne herinneringen

fijne omgeving

fluisterboten

Fotografie

Ga zelf kijken

Gasten uit de Randstad laten zien wat Overijssel te bieden heeft.

Gebied ziet er bijzonder uit op de kaart door al het water

heerlijk om de hele dag een kanotocht te maken en af en toe ergens te stoppen, bij een restaurant,

een bezienswaardigheid of iets dergelijks.

genieten van de natuur

Geocachen

Geweldig om te fietsen en het is er fantastisch mooi.

geweldig stuk natuur

het is leuk

lekker relaxen.

mooi gebied

Gezellig dagje uit

Goede camperplaatsen

Goede ervaringen, ontspannend, goed gevoel

Goede uitvalsbasis voor ons doel; tuinen bezoeken. Giethoorn overigens was een vreselijke ervaring. Te veel mensen !! Ondoenlijk om daar met een bootje te varen. Ook op de wal was het een kolkende massa.

Goeie combi bos en water

Goeie service

Heel mooi om te fietsen

Heerlijk dichtbij

Heerlijk ontspannen en genieten van het buiten zijn

heerlijk, rustgevend en gevarieerde mogelijkheid van recreeren

heimwee. vroeger met ouders elk jaar twee maal 2 weken naar Giethoorn. Heb er veel gevaren e.d.

Hel mooi gebied om te fietsen.

Helaas was dat vroeger, om te schaatsen

helpen als vrijwilliger

Het bijgelegen Rottige Meenthe is ook erg mooi om dan te bezoeken.

Het gebied in zo mooi dat wij zeker 1 keer per jaar daar gaan fietsen.

Het is een andere omgeving dan de bossen in de buurt waar we normaal gesproken wandelen.

Het is een gebied dat vrij uniek in zijn soort is. Waar ik woon/wij wonen is het ook mooi en ons land kent sowieso veel mooie plekken, dus ik 'pin' me zeker niet vast op/in De Weerribben, maar zo eens in de zoveel tijd vind ik het fijn hier de lucht op te snuiven. Bij voorkeur in de winter trouwens, dan is het m.i. mooier en veel rustiger. Kort samengevat: leuk gebied, anders dan anders, de drukte vermijden.

het is een prachtig gebied

Het is een prachtig gebied om doorheen te kanoën

Het is een prachtig gebied. Je moet het zien, ruiken en beleven om dat te ervaren! Vanaf een plaatje lukt dat niet.

Indien deze enquete voor de horeca en bootverhuurders aldaar bestemd is.... ledere keer als ik er kom, in welke horecagelegenheid dan ook. Men is de sfeer erg zakelijk en weinig kantvriendelijk. Veel horecagelegen en verhuurbedrijven van bootjes behoren tot eenzelfde eigenaar. Verandering van deze houding zal ongetwijfeld meer mensen doen besluiten nog eens terug te keren

Het is er gewoon mooi. Alleen jammer als je een fiets tocht maakt is het altijd een ellende om door Giethoorn te komen. Eigenlijk is het in het hoogseizoen niet te doen.

Het is gewoon lekker dichtbij en een geweldig park om te zijn.

Het is mijn 'achtertuin' ik woon in Blokzijl

Het is mooi en op ook uniek

het is net of je even in een ander land bent, het is er zo mooi 
Het is rustig en een mooi gebied. Er zijn niet extreem veel bedrijven daar dus de recreatie is nog niet extreem hoog. Vooral voor en na seizoen en dat trekt mij!

lets nieuws ervaren

I $\mathrm{k}$ ben er 1 keer geweest met een groep vrienden en iemand anders had het uitgekozen.

$\mathrm{lk}$ ben hier komen wonen ivm de mooie omgeving

Ik ga vaak naar de weer ribben met een groep hulpbehoevende mensen en maken een boot tocht en lekker ergens eten.

Ik geniet van het water de bruggetjes en alles om me heen ????

ik heb een huis in zwaetsluis. de tuin aan de aremberger gracht

I $k$ heb er 22 jaar gewoond en mijn familie woont er nog steeds. Hetvis als thuiskomen

I $k$ heb er mijn man ontmoet en mijn ouders hebben er 15 jaar een caravan gehad. I $k$ heb er een heel stuk van mijn jeugd liggen met mooie herinneringen.

Ik houd van natuur

ik kan het niet laten

Ik kom daar eigenlijk alleen om te karpervissen maar ondertussen kun je er wel genieten van de natuur, met name als je s'ochtends wakker wordt en je Vistent uitkomt.

Ik kom er van jongs af aan.

Ik kom hier altijd met school (hogeschool Inholland te Delft) om kennis op te doen over natuur.

Ik kon maar een mogelijkheid kwijt, maar ben afgelopen jaren o.a. met gezin, kinderfeestje met een van mijn kinderen, een familiedag, met een groot gezelschap van maandelijkse ontmoetingsgroep geweest

I $\mathrm{k}$ vind de nationale parken in Nederland geweldig omdat ze een goede indruk geven van de oorspronkelijke natuur die veelal verdreven is voor asfalt en woningen. De afwisseling in de verschillende gebieden maken het de wandelingen en fietstochten meer dan waard

I $\mathrm{k}$ vind het een fantastische gebied, ik heb in mijn jeugd tegenover de Wieden gewoond

I $\mathrm{k}$ voel het als thuis komen

I $\mathrm{k}$ was een weekend met een vriendin op stap en dit park lag daar in de buurt.

I $k$ woon aan de rand en daar ben ik heel gelukkig mee. Na 10 minuten op de fiets ben ik er.

ik woon aan de rand van het gebied, dus fietsen vanuit huis gaat automatisch daar heen. Evenzo goed is het altijd leuk om familie en / of vrienden mee te nemen naar dit prachtige gebied. De lokale bevolking zou zelf wat meer de schoonheid en de wijdsheid ervan moeten zien; trots zijn op dit gebied mag best

Ik woon er

ik woon er dichtbij. Maar men wil steeds meer natuur. Echter zie ik ook dat het onderhoud achteruit gaat.

Ik woon om de hoek in Steenwijk, dus dat is heel dichtbij. Als ik niet in de buurt zou wonen, denk ik niet dat ik er speciaal voor naartoe zal rijden. Wel is een groot voordeel dat het er minder toeristisch is als in Giethoorn.

Ja de vele soorten vogels die daar broeden.

Ja het is er gewoon goed.

Jaarlijks uitstapje van de speltdragers VBM

Jarenlang op een camping in de buurt gestaan. Heerlijke tijd gehad, dus ook een stuk nostalgie.

je 'moet' het gewoon gezien en gevoeld hebben

je kunt hier motorbootjes huren en op eigen gelegenheid het gebied verkennen. Hierbij is doorslaggevend dat in Kalenberg waar wij een bootje hadden gehuurd zonder problemen onze 5 honden mee aan boord mochten. Wanneer deze ergens niet mee mogen gaan wij hier ook niet naar toe. Dit is dus een groot pluspunt dat dit mag.

J eugdsentiment

Kinderen vinden de fluisterboot leuk

Kom er alleen als ik in de buurt ben of op vakantie ben

lekker buiten zijn

Leuke evenementen zoals de buitendag

Leuke tussenstop bij een fietstocht. Je kunt er veel doen: varen, wandelen, fietsen, bezoekerscentrum.

Libellen reservaat

Maak graag met partner fietstochten in een omgeving die anders is dan mijn thuisomgeving.

Makkelijk en dichtbij. Ophalen van jeugdherinnering 
Mee met excursies met een journalist die reportages moet maken over de wieden.

met een groep ouderen samen varen en wandelen en lekker koffie drinken en wat eten

mooi gebied om te bezoeken. Vooral voor Giethoorn gekomen, maar nu ook juist het minder

toeristische gedeelte van Giethoorn bezocht. Heel mooi om de natuur daar te zien tijdens een

vaartocht in een fluisterbootje.

natuur

natuur en ontspanning

Natuur voor libellen en juffers. Plantsoorten.

Natuurbeleving, vogels kijken

natuureducatie kinderen

uitsluitend om te vissen

voor de natuur en de stadjes zijn ook mooi. Giethoorn kom ik niet veel te druk.

Nee hoor, gewoon lekker ontspannen en genieten van de natuur en de rust.

Parkeren is wel als erg lastig ervaren.

Nieuw deel nl ontdekken

Nieuwe natuur te ontdekken

Om lekker hard te lopen en het park is haast mijn achtertuin..

Om lekker je hoofd leeg te kunnen maken

Om lekker te fietsen of te vissen en zwemmen

Om met de boot naar Friesland door te reizen.

om ontspannend te wandelen

Om van rust en ruimte te genieten in een fantastisch decor waar je niet steeds tegen andere mensen

op loopt.

omdat er zeldzame dieren en planten voorkomen

Omdat Giethoorn zo heerlijk kneuterig is, omdat het me doet denken aan vroeger.

omdat ik het een heel bijzonder en mooi gebied vind, met name in de winter als alles dik bevroren is heb ik rietmaaiers aan het werk gezien op plekken waar men anders niet kan komen, met een strak blauwe lucht en alles bedekt met een laag rijp is het een sprookjesachtige wereld!

Omdat ik hier van de serene rust en de mooie natuur die Nederland rijk is te genieten, zeker in de herfst en de winter met sneeuw. De kleinkinderen die meegaan vinden het geweldig, tis bijna een traditie. Kijk dozen maken van natuurproducten uit de WR, zoals blaadje paddenstoelen eikeltjes enz .

Super

onthaasting

Ontspannen en uitrusten

onze boot ligt in Zwartsluis en dan is een rondje weerribben voor de hand liggend. Het is een prachtig gebied dat elke keer weer anders is. We bivakkeren daar nu 17 seizoenen en het verveeld nog steeds niet

ook in combinatie met familie bezoek

oude huisjes Kalenberger gracht dicht bij overnachtingsadres

Ouders van schoondochter wonen in dit gebied. Zijn uitstekend op de hoogte wat betreft routes, restaurants, excursies etc. . Het is altijd weer mooi om hier te vertoeven.

Ouders zijn er vak op de camping,

over gelezen en leek heel leuk, doch bleek totaal ongeschikt te zijn alleen te wandelen en we hadden fietsen mee moeten nemen. De website vind ik overigens niet echt best er staat veel te weinig in over wat en waar iets exact te doen is te voet of per fiets, maw info is matig. Eerste indruk was dat het mooier werd voorgesteld dan het is, verhuur van boten is overigens heel erg duur

prachtig gebied

Recreatief

Relaxen

Roei marathon varen

's nachts naar de sterren kijken in de zomer omdat het daar lekker donker is

Samen met een groep, onderhouden we het park.

Samenzijn met familie en vrienden.

Schaatsen, zodra dat kan.

schoonheid

Sentiment, ging vroeger met mijn ouders en broers $1 x$ per jaar per zomervakantie. sfeer 
Soms is het de kortste (fiets) route naar mijn bestemming

stukje nostalgie

Tijdens de studie geleerde theorie bekijken en bestuderen in de praktijk.

toen we nog een boot hadden. Mochten we er graag varen

toeristentrekpleister voor familie/vrienden uit het buitenland

Toevallig in de buurt

traditie

Trektocht lopen.

Uitwaaien

vakantie

Vanwege een familiefeestje

varen schaatsen fietsen natuur rust (behalve in de zomer)

Vele plaatsen waar je e kano kunt huren en een route kunt varen. Een prachtig gebied en voor ons vrij dichtbij.

Viswedstrijden

Vlinders spotten!

Vogels kijken

Voldoende mogelijkheden om met een grotere groep te verblijven. Volop verhuur van bootjes.

Voor de flora en fauna.

voor familievakantie, even gezellig met zijn allen bij elkaar

voor gezelschap

voor het sportief bezig zijn buiten

VRIENDELIJ KE BEVOLKING

Vroeger vaak bezocht ivm wonen van familie daar. Gebied blijft daarom trekken

Vroeger vlakbij gewoond. Daarom kom ik er graag.

Was een kadootjes van natuurmonumenten omdat mijn echtgenote 25 jaar lid was van NM.

Water

We hebben er jaren geleden een seizoensplaats gehad op camping De Kluft in Ossenzijl. Minstens 10

jaar achter elkaar! Nu is ons kind groot en bezoeken we de Weerribben af en toe met de camper. Het

enige (best grote) nadeel zijn de knudjes.

We varen door de Weerribben van de ene haven naar een andere.

We waren er eenmalig met een groepsexcursie

Weekendje weg met mijn loopclub

Wij hebben een tweede huis in IJ sselham en daar vertoeven we zo', 20 weekends per jaar en af en toe een hele week (schoolvakanties) en we huren vaak een zeilbootje (Beulakkerwiede)

Wij rijden klassieke rally's en veel rally's spelen zich in het gebied (rondom) de weeribben af. Dan combineren we dat met een bezoek aan een van de vele natuurgebieden in de omgeving waaronder de weerribben.

Wij wonen er midden in.....en geen dag verveelt het.... Het mooiste moment van de dag na het eten ......koffiepot mee wat lekkers en in de punter over de Wieden varen. Rustig slootje in en lekker genieten van de vogels....en verder in het jaar , ,.,., dagje vroeg op.....emmertje mee ....oude kleren aan en bramen plukken.......weer terug ...lekker jam koken......!!!Mooiste dagen van het jaar!!!!!!! Dan hoeven wij niet op vakantie....laat ons maar lekker hier in en op de Wieden!!!!!!!

Wij zijn er 1x geweest om er doorheen te fietsen. Geen idee of we er nog een keer komen maar het was erg mooi. Nederland heeft $\mathrm{nl}$ nog meer mooie plekken die een bezichtiging waard zijn Wij zijn er eenmaal geweest afgelopen november voor het eerst door een vriendenweekend. Mooi gebied dat ik zeker nog wel eens zou willen bezoeken. 
Wageningen Environmental Research Postbus 47

6700 AA Wageningen

T 0317480700

www.wur.nl/environmental-research

Wageningen Environmental Research Rapport 2798

ISSN 1566-7197
De missie van Wageningen University \& Research is 'To explore the potential of nature to improve the quality of life'. Binnen Wageningen University \& Research bundelen Wageningen University en gespecialiseerde onderzoeksinstituten van Stichting Wageningen Research hun krachten om bij te dragen aan de oplossing van belangrijke vragen in het domein van gezonde voeding en leefomgeving. Met ongeveer 30 vestigingen, 5.000 medewerkers en 10.000 studenten behoort Wageningen University \& Research wereldwijd tot de aansprekende kennisinstellingen binnen haar domein. De integrale benadering van de vraagstukken en de samenwerking tussen verschillende disciplines vormen het hart van de unieke Wageningen aanpak. 



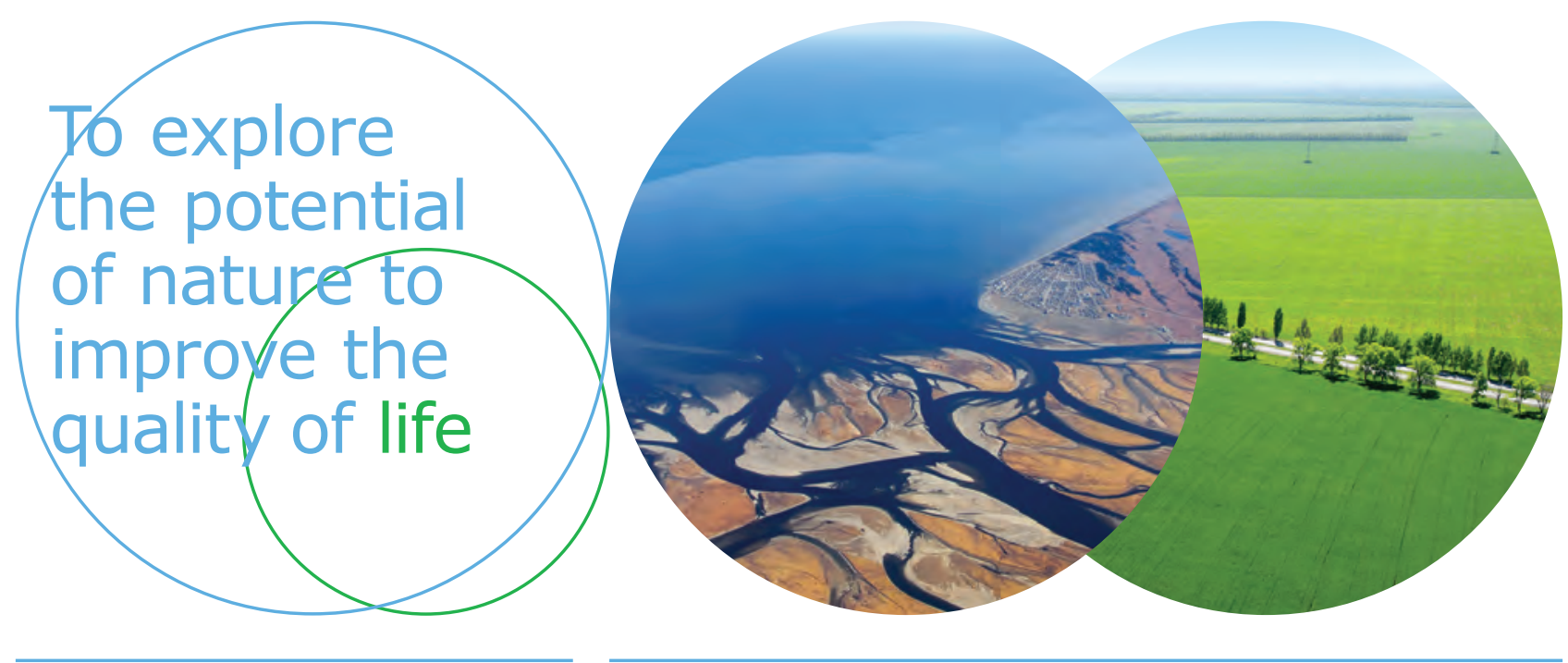

Wageningen Environmental Research Postbus 47

$6700 \mathrm{AB}$ Wageningen

T 317480700

www.wur.nl/environmental-research

Rapport 2798

ISSN 1566-7197
De missie van Wageningen University \& Research is 'To explore the potential of nature to improve the quality of life'. Binnen Wageningen University \& Research bundelen Wageningen University en gespecialiseerde onderzoeksinstituten van Stichting Wageningen Research hun krachten om bij te dragen aan de oplossing van belangrijke vragen in het domein van gezonde voeding en leefomgeving. Met ongeveer 30 vestigingen, 5.000 medewerkers en 10.000 studenten behoort Wageningen University \& Research wereldwijd tot de aansprekende kennisinstellingen binnen haar domein. De integrale benadering van de vraagstukken en de samenwerking tussen verschillende disciplines vormen het hart van de unieke Wageningen aanpak. 